\title{
Effects of Low pH on Photosynthesis, Related Physiological Parameters, and Nutrient Profiles of Citrus
}

\author{
An Long ${ }^{1}$, Jiang Zhang ${ }^{1}$, Lin-Tong Yang ${ }^{1}$, Xin Ye ${ }^{1}$, Ning-Wei Lai ${ }^{1}$, Ling-Ling Tan ${ }^{1}$, Dan Lin ${ }^{1}$ \\ and Li-Song Chen ${ }^{1,2,3 *}$ \\ ${ }^{1}$ Institute of Plant Nutritional Physiology and Molecular Biology, College of Resources and Environment, Fujian Agriculture \\ and Forestry University, Fuzhou, China, ${ }^{2}$ Fujian Provincial Key Laboratory of Soil Environmental Health and Regulation, \\ College of Resources and Environment, Fujian Agriculture and Forestry University, Fuzhou, China, ${ }^{3}$ The Higher Educational \\ Key Laboratory of Fujian Province for Soil Ecosystem Health and Regulation, Fujian Agriculture and Forestry University, \\ Fuzhou, China
}

OPEN ACCESS

Edited by:

Jairo A. Palta,

University of Western Australia,

Australia

Reviewed by:

Xuming Huang,

South China Agricultural University

China

Mei Yang,

Guangxi University of China, China

*Correspondence:

Li-Song Chen

lisongchen2002@hotmail.com

Specialty section:

This article was submitted to Crop Science and Horticulture, a section of the journal

Frontiers in Plant Science

Received: 26 October 2016 Accepted: 30 January 2017 Published: 21 February 2017

Citation:

Long A, Zhang J, Yang L-T, Ye X, Lai N-W, Tan L-L, Lin D and Chen L-S

(2017) Effects of Low pH on Photosynthesis, Related Physiological

Parameters, and Nutrient Profiles of Citrus. Front. Plant Sci. 8:185 doi: 10.3389/fpls.2017.00185
Seedlings of "Xuegan" (Citrus sinensis) and "Sour pummelo" (Citrus grandis) were irrigated daily with a nutrient solution at a $\mathrm{pH}$ of $2.5,3,4,5$, or 6 for 9 months. Thereafter, the following responses were investigated: seedling growth; root, stem, and leaf concentrations of nutrient elements; leaf gas exchange, pigment concentration, ribulose-1,5-bisphosphate carboxylase/oxygenase activity and chlorophyll a fluorescence; relative water content, total soluble protein level, $\mathrm{H}_{2} \mathrm{O}_{2}$ production and electrolyte leakage in roots and leaves. This was done (a) to determine how low $\mathrm{pH}$ affects photosynthesis, related physiological parameters, and mineral nutrient profiles; and (b) to understand the mechanisms by which low $\mathrm{pH}$ may cause a decrease in leaf $\mathrm{CO}_{2}$ assimilation. The $\mathrm{pH} 2.5$ greatly inhibited seedling growth, and many physiological parameters were altered only at $\mathrm{pH} 2.5$; $\mathrm{pH} 3$ slightly inhibited seedling growth; $\mathrm{pH} 4$ had almost no influence on seedling growth; and seedling growth and many physiological parameters reached their maximum at $\mathrm{pH} 5$. No seedlings died at any given $\mathrm{pH}$. These results demonstrate that citrus survival is insensitive to low $\mathrm{pH} . \mathrm{H}^{+}$-toxicity may directly damage citrus roots, thus affecting the uptake of mineral nutrients and water. $\mathrm{H}^{+}$-toxicity and a decreased uptake of nutrients (i.e., nitrogen, phosphorus, potassium, calcium, and magnesium) and water were likely responsible for the low $\mathrm{pH}$-induced inhibition of growth. Leaf $\mathrm{CO}_{2}$ assimilation was inhibited only at $\mathrm{pH} 2.5$. The combinations of an impaired photosynthetic electron transport chain, increased production of reactive oxygen species, and decreased uptake of nutrients and water might account for the $\mathrm{pH} 2.5$-induced decrease in $\mathrm{CO}_{2}$ assimilation. Mottled bleached leaves only occurred in the $\mathrm{pH}$ 2.5-treated $\mathrm{C}$. grandis seedlings. Furthermore, the $\mathrm{pH}$ 2.5-induced alterations of leaf $\mathrm{CO}_{2}$ assimilation, water-use efficiency, chlorophylls, polyphasic chlorophyll a fluorescence (OJIP) transients and many fluorescence parameters, root and leaf total soluble proteins, $\mathrm{H}_{2} \mathrm{O}_{2}$ production, and electrolyte leakage were all slightly greater in $\mathrm{C}$. grandis than in C. sinensis seedlings. Hence, C. sinensis was slightly more tolerant to low $\mathrm{pH}$ than $\mathrm{C}$. grandis. In conclusion, our findings provide novel insight into the causes of low pH-induced inhibition of seedling growth and leaf $\mathrm{CO}_{2}$ assimilation.

Keywords: chlorophyll a fluorescence, Citrus grandis, Citrus sinensis, low pH, OJIP transient, photosynthesis, uptake of nutrient and water 


\section{INTRODUCTION}

Acidic soils that limit crop growth and productivity are often observed all over the world, especially in the tropics and subtropics. Approximately $30 \%$ of the world's ice-free land is acidic, and approximately $12 \%$ of crops are cultivated on acidic soils (von Uexküll and Mutert, 1995). What is worse, soil acidification is becoming an increasingly major problem due to the improper application of chemical fertilizers-particularly the overuse of nitrogen $(\mathrm{N})$ fertilizers-alongside acid rain and intensive agriculture and monoculture (Wu et al., 2013; Yang et al., 2013). The effects of aluminum (Al)-toxicity-a major factor limiting crop productivity on acidic soils-on plants have drawn widespread attention, but few studies have investigated the damage to plants from low $\mathrm{pH}$ (Yang et al., 2015).

Poor crop growth and yield on acidic soils is usually due to the combination of toxicities of $\mathrm{H}^{+}, \mathrm{Al}$, and manganese $(\mathrm{Mn})$ and a lack of nutrients-namely phosphorus $(\mathrm{P})$, calcium $(\mathrm{Ca})$, magnesium $(\mathrm{Mg})$, potassium $(\mathrm{K})$, and molybdenum (Mo) - and a reduced uptake of water (von Uexküll and Mutert, 1995; Bian et al., 2013). In tropical America, over 70\% of the acidic soils display $\mathrm{Al}$-toxicity and $\mathrm{Mg}$ and $\mathrm{Ca}$ deficiencies, and almost all the acidic soils are P-deficient or have a high P-fixation capacity (George et al., 2012). For example, Zhang et al. (2014) showed that $\mathrm{pH} 3.0$ decreased the uptake and utilization efficiency of $\mathrm{P}$ in Juglans regia seedlings. Forest ecosystems with acidic soils are often restricted by low Ca and Mg availability (St Clair and Lynch, 2005). Schubert et al. (1990) showed that transferring Vicia faba plants from $\mathrm{pH} 7$ to $\mathrm{pH} 4$ led to the reduced uptake of $\mathrm{N}, \mathrm{P}, \mathrm{K}, \mathrm{Ca}$, $\mathrm{Mg}$, and sulfur (S). Malkanthi et al. (1995) observed that the levels of $\mathrm{K}, \mathrm{Ca}, \mathrm{Mg}, \mathrm{Mn}$, and $\mathrm{Zn}$ in the roots and tops of wheat, barley, and chili plants were lower at $\mathrm{pH} 3.8$ than at $\mathrm{pH}$ 5.5. Similarly, the $\mathrm{K}, \mathrm{Ca}, \mathrm{Mg}$, and $\mathrm{Mn}$ levels in Pinus pinaster roots and needles were lower at $\mathrm{pH} 3.5$ than at $\mathrm{pH} 4.5,5.5$, and 6.5 , whereas the levels of $\mathrm{P}$ and Fe were higher at $\mathrm{pH} 3.5$ and 4.5 than at $\mathrm{pH} 5.5$ and 6.5 (Arduini et al., 1998). However, Anugoolprasert et al. (2012) reported that the uptake of N, P, K, Ca, and Mg, and their concentration in roots, leaflets, petioles and whole plant, were not altered over the range of $\mathrm{pH} 3.6$ to 5.7 for 4.5 months; this possibly explains the normal growth of sago palm seedlings at pH 3.6. Kidd and Proctor (2001) have suggested that the direct toxicity of $\mathrm{H}^{+}$was the primary cause of the poor growth in $\mathrm{H}^{+}$-intolerant plants growing in very acidic soils.

Low $\mathrm{pH}$ can affects plant water uptake. Kamaluddin and Zwiazek (2004) observed that low $\mathrm{pH}$ caused a large and rapid decrease in both the water flow rate and the hydraulic conductivity in seedling roots of paper birch (Betula papyrifera). A pH 4.5 decreased the whole-root water conductivity in the $\mathrm{H}^{+}$-sensitive maize cultivar Adour 250, but it did not in the $\mathrm{H}^{+}$tolerant maize cultivar BR 201 F (Gunsé et al., 1997). TournaireRoux et al. (2003) showed that the inhibition of water hydraulic conductivity (water uptake) in Arabidopsis roots by anoxia was primarily caused by cytosol acidosis, while changing the $\mathrm{pH}$ between 5.5 and 8.0 of a root-bathing solution did not affect the cytosol $\mathrm{pH}$ nor the root water hydraulic conductivity. Finally, Yang M. et al. (2011) observed that a low pH decreased the water content in Eucalyptus roots, stems, and leaves.
Low $\mathrm{pH}$ also inhibits $\mathrm{CO}_{2}$ assimilation in some plant species, including J. regia (Zhang et al., 2014), Eucalyptus (Yang et al., 2015), sugar maple (Acer saccharum) and red maple (Acer rubrum) (Ellsworth and Liu, 1994; St Clair and Lynch, 2005). St Clair and Lynch (2005) also reported that the base cation stimulation of photosynthesis in sugar maple on acidic soils was correlated with its foliar nutrient status. Ellsworth and Liu (1994) had earlier suggested that photosynthesis in sugar maple on acidic soils might be co-limited by $\mathrm{N}$ and $\mathrm{Ca}$, or by $\mathrm{Ca}$ $\times$ Mg interactions. Yang M. et al. (2011) observed that a low $\mathrm{pH}$ decreased the chlorophyll (Chl) level in Eucalyptus leaves. Yang et al. (2015) further investigated the effects of low $\mathrm{pH}$ on leaf gas exchange and $\mathrm{Chl}$ in four vegetatively-propagated Eucalyptus clones (G9, G12, G3, and G4); they found that pH 3.0 decreased leaf photosynthesis, transpiration, and Chl level in the four clones as well as the leaf water-use efficiency (WUE) in the G4 leaves, but pH 3.0 did not affect WUE in the G9, G12, and G3 leaves. Zhang et al. (2014) reported that pH 3.0 decreased the leaf net photosynthetic rate, transpiration rate, actual quantum yield of the photosystem II (PSII) electron transport ( $\left.\Phi_{\mathrm{PSII}}\right)$, whereas it increased leaf non-photochemical quenching (NPQ); however, $\mathrm{pH} 3$ had no effect upon leaf stomatal conductance, photochemical quenching $(\mathrm{qP})$, and the maximum PSII efficiency of dark-adapted leaves $\left(\mathrm{F}_{\mathrm{v}} / \mathrm{F}_{\mathrm{m}}\right)$, thus leading the authors to conclude that non-stomatal factors played a role in the low $\mathrm{pH}$ induced inhibition of photosynthesis. Nonetheless, $\mathrm{pH} 4.0 \mathrm{did}$ not influence spatial heterogeneity of Chl fluorescence, $\mathrm{F}_{\mathrm{v}} / \mathrm{F}_{\mathrm{m}}$, $\Phi_{\mathrm{PSII}}$, and quantum yields of regulated $\left(\Phi_{\mathrm{NPQ}}\right)$ and nonregulated $\left(\Phi_{\mathrm{NO}}\right)$ energy dissipation in the leaves of Plantago algarbiensis and P. almogravensis (Martins et al., 2013a,c). Altering the $\mathrm{pH}$ between 5.7 and 3.6 did not reduce the Chl concentration, photosynthetic rate, stomatal conductance, and transpiration rate in sago palm leaves (Anugoolprasert et al., 2012). However, to our best knowledge, little is still known about the effects of low $\mathrm{pH}$ on PSII photochemistry (i.e., absorption flux, trapped energy flux, electron flux, and dissipated energy flux) of leaves.

Low $\mathrm{pH}$ can induce oxidative stress and electrolyte leakage via the enhanced production of active oxygen species (ROS). Martins et al. (2013b) found that lipid peroxidation (malondialdehyde, MDA) was elevated in the $\mathrm{pH}$ 4.0-treated $P$. algarbiensis shoots, but not in the $\mathrm{pH}$ 4.0-treated $P$. almogravensis ones, and that the activities of antioxidant enzymes were enhanced or not affected in the shoots of the two Plantago species-suggesting that the higher antioxidant enzyme activities were insufficient to protect the low $\mathrm{pH}$-treated $P$. algarbiensis shoots against oxidative damage. In another experiment, Martins et al. (2011) observed that $\mathrm{pH} 4.5$ led to an increase in the MDA level in $P$. algarbiensis roots and shoots and $P$. almogravensis roots, but not in P. almogravensis shoots. Yang M. et al. (2011) reported that low $\mathrm{pH}$ increased membrane permeability in Eucalyptus leaves. Hydroponic experimentation showed that $\mathrm{pH} 3.5$ led to an accumulation of $\mathrm{H}_{2} \mathrm{O}_{2}$ and severe lipid peroxidation that was accompanied by an increased activity of ascorbate peroxidase (APX) and decreased activities of superoxide dismutase (SOD) and catalase (CAT) in the roots of two rice cultivars (Zhang et al., 2015). Cucumber roots treated with $\mathrm{pH} 4.5$ had a higher level of MDA and activities of monodehydroascorbate reductase 
(DHAR), guaiacol peroxidase (GPX), APX, and glutathione reductase (GR), but had lower activities of $\mathrm{Cu} / \mathrm{Zn}-\mathrm{SOD}$, than did the $\mathrm{pH}$ 6.5-treated roots (Shi et al., 2006). However, $\mathrm{pH} 4.0$ did not affect $\mathrm{H}_{2} \mathrm{O}_{2}, \mathrm{MDA}$ and the total soluble protein levels, electrolyte leakage, protein oxidation, and the SOD, CAT, APX, and GPX activities in the roots and leaves of $P$. algarbiensis and P. almogravensis (Martins et al., 2013c).

Citrus plants are considered insensitive to acidic soils (Yuda and Okamoto, 1965). Fang et al. (2011) used a solution culture approach to investigate the effects of $\mathrm{pH} 1.0,2.0,3.0,4.0,5.0$, and 6.0 on several citrus rootstock seedlings. At $\mathrm{pH} 1.0$, all seedlings died within 10 days after treatment, but the $\mathrm{pH} 4$ treated seedlings showed normal growth except for a yellow tip that occurred in some leaves within 30 days. Using sand and solution cultures, Guest and Chapman (1944) found that Citrus sinensis seedlings died within a few days at $\mathrm{pH} 2.0$, but they were not killed for months at $\mathrm{pH} 2.5$ and 3.0 though their growth was limited or negligible. Nevertheless, citrus do not thrive in trongly acidic soils, because serious problems may arise when the soil $\mathrm{pH}$ is 5.0 or lower (Chapman, 1968). Citrus will often display poor growth and have a shortened lifespan when cultivated on soil with a low $\mathrm{pH}$ and high active $\mathrm{Al}$ (Lin and Myhre, 1990). In China, most of the citrus are grown in acidic and strongly acidic soils. Li et al. (2015) reported that the $\mathrm{pH}$ values of 319 soils sampled from pummelo (Citrus grandis) orchards in Pinghe, Zhangzhou, China had an average value of 4.34 and ranged from 3.26 to 6.22 , with up to $90.0 \%$ of the orchard soils having a $\mathrm{pH}$ lower than 5.0. So far, however, only a handful of reports have empirically investigated the effects of low $\mathrm{pH}$ on citrus growth (Yuda and Okamoto, 1965), mineral nutrient uptake (Randhawa and Iwata, 1968; He et al., 1999; Li et al., 2015), and ROS metabolism alongside a few other physiological parameters (Fang, 2011). Randhawa and Iwata (1968) reported that the $\mathrm{N}, \mathrm{Ca}$, and $\mathrm{Mg}(\mathrm{Ca}, \mathrm{Mg}$, and $\mathrm{P})$ levels decreased in the leaves (roots), whereas the $\mathrm{K}$ level increased in the roots and leaves of Citrus natsudaidai seedlings, as the $\mathrm{pH}$ decreased from 7.0 to 4.0. He et al. (1999) observed that $\mathrm{Fe}, \mathrm{Zn}$, and $\mathrm{Mn}(\mathrm{Ca})$ in grapefruit (Citrus paradisi) leaves increased (decreased) with decreasing soil $\mathrm{pH}$. The concentration of $\mathrm{P}$ and $\mathrm{Ca}$ in pummelo leaves decreased with decreasing soil pH (Li et al., 2015). Fang (2011) found that the activities of SOD, GPX, and CAT and the level of total soluble proteins displayed an upward trend, as a whole, as the $\mathrm{pH}$ decreased from 6.0 to 2.0; in contrast, the level of MDA decreased first to reach its lowest value at $\mathrm{pH} 4$, but then increased as the $\mathrm{pH}$ decreased further.

The objectives of this work were $(a)$ to determine how low $\mathrm{pH}$ affects gas exchange, related physiological parameters, and the mineral nutrient profiles in citrus seedlings; and $(b)$ to understand the mechanisms by which low $\mathrm{pH}$ may lead to a decrease in leaf $\mathrm{CO}_{2}$ assimilation.

\section{MATERIALS AND METHODS}

\section{Plant Materials and Culture Conditions}

This study was conducted at the Fujian Agriculture and Forestry University (FAFU) in Fuzhou, China. Seedling culture was performed according to Han et al. (2008) and Peng et al. (2015), with some modifications. Briefly, seeds of "Sour pummelo"
(C. grandis) and "Xuegan" (C. sinensis) were germinated in plastic trays filled with clean river sand. Four weeks after germination, uniform seedlings that had a single stem were chosen and transplanted into 6-L terracotta pots (two seedlings per pot) containing clean river sand. Seedlings were grown in a greenhouse under a natural photoperiod at FAFU. One week after transporting, each pot was irrigated every other day with $500 \mathrm{~mL}$ of a nutrient solution containing $2.5 \mathrm{mM} \mathrm{Ca}\left(\mathrm{NO}_{3}\right)_{2}, 2.5 \mathrm{mM}$ $\mathrm{KNO}_{3}, 1 \mathrm{mM} \mathrm{MgSO} 4,0.5 \mathrm{mM} \mathrm{KH}{ }_{2} \mathrm{PO}_{4}, 20 \mu \mathrm{M}$ Fe-EDTA, 10 $\mu \mathrm{M} \mathrm{H}_{3} \mathrm{BO}_{3}, 2 \mu \mathrm{M} \mathrm{MnCl}_{2}, 2 \mu \mathrm{M} \mathrm{ZnSO}_{4}, 0.5 \mu \mathrm{M} \mathrm{CuSO}_{4}$, and $0.065 \mu \mathrm{M}\left(\mathrm{NH}_{4}\right)_{6} \mathrm{Mo}_{7} \mathrm{O}_{24}$. Seven weeks after transplanting, each pot was fertilized daily until saturated with the same nutrient solution (approximately $500 \mathrm{~mL}$ ), except that the $\mathrm{pH}$ of the nutrient solution was adjusted to $2.5,3,4,5$, or 6 with $1 \mathrm{M} \mathrm{HCl}$. There were 20 replicates (20 pots, 40 seedlings) per treatment in a completely randomized design. In this experiment, the pH 5 treatment served as the control because seedling growth and many physiological parameters reach their maximum at $\mathrm{pH}$ 5. Nine months after the $\mathrm{pH}$ treatment began, recent fullyexpanded (approximately 7-week-old) leaves and approximately 5-mm-long white root apices were used for all measurements except that for root mineral element concentrations. After leaf gas exchange and $\mathrm{Chl}$ a fluorescence were measured, leaf disks $\left(0.2826 \mathrm{~cm}^{2}\right.$ in size $)$ and approximately 5 -mm-long white root apices from the same seedlings were harvested from randomly selected seedling at noon on a sunny day and immediately frozen in liquid $\mathrm{N}_{2}$, then stored at $-80^{\circ} \mathrm{C}$ until they were used for the assays of ribulose-1,5-bisphosphate carbohylase/oxygenase (Rubisco), total soluble proteins, and pigments. The remaining seedlings that were not sampled were selected randomly to measure plant biomass, root and leaf relative water content (RWC), and electrolyte leakage, and the root, stem and leaf mineral element concentrations.

\section{Measurements of Leaf, Stem and Root Dry Weight (DW), and Specific Leaf Weight}

Nine months after the $\mathrm{pH}$ treatment began, 10 seedlings per treatment from 10 pots were collected. The seedlings were divided into leaves, stems, and roots. Their DW was measured after being dried at $70^{\circ} \mathrm{C}$ for $48 \mathrm{~h}$. Specific leaf weight was calculated as the ratio of leaf weight to leaf area.

\section{Leaf Pigments, and Root and Leaf Total Soluble Proteins}

Leaf pigments were extracted with $80 \%(\mathrm{v} / \mathrm{v})$ acetone. The Chl, $\mathrm{Chl} \mathrm{a}$ and $\mathrm{Chl} \mathrm{b}$, and carotenoids (Car) in the extract were determined according to Lichtenthaler (1987).

Root and leaf total soluble proteins were extracted with $50 \mathrm{mM} \mathrm{KH} \mathrm{PO}_{4}-\mathrm{Na}_{2} \mathrm{HPO}_{4}(\mathrm{pH} 7.0)$ and $5 \%(\mathrm{v} / \mathrm{v})$ insoluble polyvinylpyrrilodone (PVP), and assayed according to Bradford (1976).

\section{Electrolyte Leakage, RWC, and $\mathrm{H}_{2} \mathrm{O}_{2}$ Production}

Root and leaf electrolyte leakage was assayed according to Han et al. (2008). Briefly, 20 fresh leaf disks $\left(0.2826 \mathrm{~cm}^{2}\right.$ in size) from 
the same leaf or 20 approximately 5 -mm-long white root apices taken at midday under full sun, were immediately transferred to a $50-\mathrm{mL}$ tube filled with $15 \mathrm{~mL}$ of distilled water. The tubes were placed at room temperature in the dark for $24 \mathrm{~h}$ and the first electrical conductance $\left(\mathrm{C}_{1}\right)$ was measured. Then the tubes were incubated in a boiling water bath for $15 \mathrm{~min}$ and the second electrical conductance $\left(\mathrm{C}_{2}\right)$ was measured after being cooled. The electrolyte leakage was calculated as: electrolyte leakage (\%) = $\left(\mathrm{C}_{1} / \mathrm{C}_{2}\right) \times 100$.

Root and leaf RWC were gravimetrically determined (Panković et al., 1999). After fresh weight (FW) was measured, approximately $0.2 \mathrm{~g}$ of roots and $0.5 \mathrm{~g}$ of leaves were floated on distilled water in Petri dishes in the dark. After reaching a constant turgid weight (ca. $6 \mathrm{~h}$ ), the roots and leaves were dried. The RWC was calculated as: RWC $(\%)=(\mathrm{FW}-\mathrm{DW}) /($ turgid weight - DW) $\times 100$.

Root and leaf $\mathrm{H}_{2} \mathrm{O}_{2}$ production were determined according to Chen et al. (2005b). About $100 \mathrm{mg}$ of roots and 15 leaf disks $\left(0.2826 \mathrm{~cm}^{2}\right.$ in size) were incubated in $2 \mathrm{~mL}$ of a $50 \mathrm{mM}$ phosphate buffer ( $\mathrm{pH} 7.0), 5 \mathrm{U}$ horseradish GPX, and $0.05 \%$ $(\mathrm{w} / \mathrm{v})$ guaiacol for $2 \mathrm{~h}$ at room temperature in the dark. Then the absorbance was measured at $470 \mathrm{~nm}$.

\section{Measurements of Mineral Elements, and the Calculation of Nutrient Uptake and Element Distribution in Roots, Stems, and Leaves}

Fibrous roots, the middle sections of stems, and approximately 7-week-old leaves (midribs and petioles removed) were collected and dried at $70^{\circ} \mathrm{C}$ for $48 \mathrm{~h}$. Dried samples were ground in a mortar to pass through a 40-mesh sieve and stored for later analysis.

To measure the root, stem, and leaf concentrations of $\mathrm{P}, \mathrm{K}, \mathrm{Fe}, \mathrm{Mn}, \mathrm{Cu}, \mathrm{Zn}, \mathrm{Ca}$, and $\mathrm{Mg}$, approximately $0.3-\mathrm{g}$ samples were digested in a $7 \mathrm{~mL}$ mixture of $\mathrm{HNO}_{3}: \mathrm{H}_{2} \mathrm{O}_{2}$ $(5: 2 \mathrm{v} / \mathrm{v})$. $\mathrm{P}$ was determined colorimetrically as the blue molybdate-phosphate complexes according to Lu (1999). K was assayed using FP640 Flame Photometry (Shanghai Precision Scientific Instrument Co., Ltd, Shanghai, China). Fe, Mn, $\mathrm{Cu}, \mathrm{Zn}, \mathrm{Ca}$, and $\mathrm{Mg}$ were determined using a PinAAcle 900F Atomic Absorption Spectrometer (Perkinelmer Singapore Pte Ltd, Singapore). N was measured using a Kjeltec 8200 Auto Distillation (FOSS Analytical AB, Höganäs, Sweden) after samples had been digested with $\mathrm{H}_{2} \mathrm{SO}_{4}$ and $\mathrm{H}_{2} \mathrm{O}_{2}$ ( $\mathrm{Lu}, 1999$ ). $\mathrm{B}$ was determined by the curcumin method after samples were ashed at $500^{\circ} \mathrm{C}$ for $5 \mathrm{~h}$ and dissolved in $0.1 \mathrm{M} \mathrm{HCl}$ (Kowalenko and Lavkulich, 1976). S was assayed using the simple turbidimetric method based on the formation of the $\mathrm{BaSO}_{4}$ precipitate in its colloid form after approximately 0.3 -g samples were digested with a 6-mL mixture of $\mathrm{HNO}_{3}: \mathrm{HClO}_{4}(4: 1 \mathrm{v} / \mathrm{v}$; $\mathrm{Lu}$, 1999).

Nutrient uptake per plant was the sum of the element content (element concentration $\times$ tissue DW) in the roots, stems, and leaves. Element distributions in roots, stems, or leaves (\%) were calculated as: (element content in roots, stems, or leaves/the sum of element content in roots, stems, and leaves) $\times 100$.

\section{Leaf Gas Exchange and Rubisco Measurements}

Leaf gas exchange was measured by a CIARS-2 portable photosynthesis system (PP Systems, Herts, UK) at an ambient $\mathrm{CO}_{2}$ concentration under a controlled light intensity of 996-1004 $\mu \mathrm{mol} \mathrm{m}{ }^{-2} \mathrm{~s}^{-1}$ between 9:30 and 12:30 on a clear day. During all of these measurements, the leaf temperature and relative humidity were $30.0 \pm 0.2^{\circ} \mathrm{C}$ and $64.5 \pm 0.6 \%$, respectively. Leaf Rubisco was extracted and assayed according to Chen et al. (2005a) and Lin et al. (2009), respectively.

\section{Measurements of Leaf OJIP Transients by Handy PEA and the JIP Test}

The polyphasic Chl a fluorescence (OJIP) transients were measured by a Handy Plant Efficiency Analyzer (Handy PEA, Hansatech Instruments Limited, Norfolk, UK). The transient was induced by a saturating red light of approximately 3,400 $\mu \mathrm{mol}$ $\mathrm{m}^{-2} \mathrm{~s}^{-1}$, which was provided by an array of three light-emitting diodes (peak $650 \mathrm{~nm}$ ) that were focused on the leaf surface to provide homogenous illumination over the exposed area of the leaf. All the measurements were performed on 3-h dark-adapted plants at room temperature.

The OJIP transients were analyzed according to the JIP test (Strasser et al., 2004; Jiang et al., 2008; Chen and Cheng, 2009). The following data from the original measurements were extracted and used: fluorescence intensities at $20 \mu \mathrm{s}\left(\mathrm{F}_{20 \mu s}\right.$, considered as the minimum fluorescence $\left.\mathrm{F}_{\mathrm{o}}\right), 50 \mu \mathrm{s}\left(\mathrm{F}_{50 \mu s}\right), 300$ $\mu \mathrm{s}\left(\mathrm{F}_{300 \mu s}\right), 2 \mathrm{~ms}$ (J-step, $\left.\mathrm{F}_{\mathrm{J}}\right), 30 \mathrm{~ms}$ (I-step, $\mathrm{F}_{\mathrm{I}}$ ), and P-step (considered as the maximum fluorescence $\mathrm{F}_{\mathrm{m}}$ ). The following parameters that refer to "time 0" (start of fluorescence induction) are: (a) fluorescence parameters derived from the extracted data, i.e., the maximum variable fluorescence $F_{v}=F_{m}-F_{o}$ and the approximated initial slope (in $\mathrm{ms}^{-1}$ ) of the fluorescence transient $\mathrm{V}=\mathrm{f}(\mathrm{t})\left[\mathrm{M}_{\mathrm{o}}=4\left(\mathrm{~F}_{300 \mu s}-\mathrm{F}_{\mathrm{o}}\right) /\left(\mathrm{F}_{\mathrm{m}}-\mathrm{F}_{\mathrm{o}}\right)\right] ;(b)$ the specific energy fluxes per reaction center $(\mathrm{RC})$ for energy dissipation $\left(\mathrm{DI}_{\mathrm{o}} / \mathrm{RC}\right)$ and absorption (ABS/RC); (c) the yields of the flux ratios, i.e., quantum yield for energy dissipation $\left(\varphi_{\mathrm{Do}}=\mathrm{DI}_{\mathrm{o}} / \mathrm{ABS}=\mathrm{F}_{\mathrm{o}} / \mathrm{F}_{\mathrm{m}}\right)$, maximum quantum yield of primary photochemistry $\left(\varphi_{\mathrm{Po}}=\right.$ $\left.\mathrm{TR}_{\mathrm{o}} / \mathrm{ABS}=\mathrm{F}_{\mathrm{v}} / \mathrm{F}_{\mathrm{m}}\right)$, quantum yield for the reduction of the end acceptors of photosystem I (PSI) per photon absorbed $\left(\varphi_{\text {Ro }}=\right.$ $\left.\mathrm{RE}_{\mathrm{o}} / \mathrm{ABS}\right)$, and quantum yield for electron transport $\left(\varphi_{\mathrm{Eo}}=\right.$ $\left.\mathrm{ET}_{\mathrm{o}} / \mathrm{ABS}\right) ;(d)$ the overall grouping probability $\left(\mathrm{P}_{2 \mathrm{G}}\right)$; and $(e)$ the total performance index $\left(\mathrm{PI}_{\text {tot,abs }}\right)$.

\section{Measurements of Conventional Fluorescence Parameters by FMS-2}

Conventional fluorescence parameters were determined by a pulse-modulated fluorometer FMS-2 (Hansatech Instruments, Norfolk, UK). Both $\mathrm{F}_{\mathrm{m}}$ and $\mathrm{F}_{\mathrm{o}}$ were measured after the leaves were dark-adapted for $40 \mathrm{~min}$. Steady-state fluorescence $\left(\mathrm{F}_{\mathrm{s}}\right)$ and the maximum $\left(\mathrm{F}_{\mathrm{m}}{ }^{\prime}\right)$ and minimum $\left(\mathrm{F}_{\mathrm{o}}{ }^{\prime}\right)$ fluorescences were measured under natural light at midday in full sun. For this determination, the $\mathrm{F}_{\mathrm{s}}$ was monitored to ensure it was stable before a reading was taken; the $\mathrm{F}_{\mathrm{m}}{ }^{\prime}$ was obtained by imposing a 1-s saturating flash of approximately $6,000 \mu \mathrm{mol}$ $\mathrm{m}^{-2} \mathrm{~s}^{-1}$ at the leaf surface to reduce all the PSII centers. To 
measure the $\mathrm{F}_{\mathrm{o}}{ }^{\prime}$, a black cloth covered the leaf when a far-red light was switched on to rapidly oxidize the PSII centers by drawing electrons from PSII to PSI. The NPQ was calculated as: $\mathrm{F}_{\mathrm{m}} / \mathrm{F}_{\mathrm{m}}{ }^{\prime}-1$. The photochemical quenching coefficient, $\mathrm{qP}$, was expressed as: $\left(\mathrm{F}_{\mathrm{m}}{ }^{\prime}-\mathrm{F}_{\mathrm{s}}\right) /\left(\mathrm{F}_{\mathrm{m}}{ }^{\prime}-\mathrm{F}_{\mathrm{o}}{ }^{\prime}\right)$. The non-photochemical quenching coefficient, $q N P$, was defined as: $\left(\mathrm{F}_{\mathrm{m}}-\mathrm{F}_{\mathrm{m}}{ }^{\prime}\right) /\left(\mathrm{F}_{\mathrm{m}}-\mathrm{F}_{\mathrm{o}}{ }^{\prime}\right)$. The $\Phi_{\text {PSII }}$ was calculated as: $\left(\mathrm{F}_{\mathrm{m}}{ }^{\prime}-\mathrm{F}_{\mathrm{s}}\right) / \mathrm{F}_{\mathrm{m}}{ }^{\prime}$. The efficiency of excitation transfer to PSII RCs under natural light $\left(\mathrm{F}_{\mathrm{m}}{ }^{\prime} / \mathrm{F}_{\mathrm{v}}{ }^{\prime}\right)$ was defined as: $\left(\mathrm{F}_{\mathrm{m}}{ }^{\prime}-\mathrm{F}_{\mathrm{o}}{ }^{\prime}\right) / \mathrm{F}_{\mathrm{m}}{ }^{\prime}$. Finally, the electron transport rate through PSII was estimated from $\left(\mathrm{F}_{\mathrm{m}}{ }^{\prime}-\mathrm{F}_{\mathrm{s}}\right) / \mathrm{F}_{\mathrm{m}}{ }^{\prime} \times 0.5 \times$ LA $\times$ photosynthetic photon flux $(\mathrm{PPF})$, for which the PSI photochemistry was assumed equivalent to that of PSII (Genty et al., 1990), and where LA is the leaf absorbance (0.84; Baker, 2008).

\section{Statistical Analysis}

There were 10 replicates for plant biomass; three replicates for Rubisco; four replicates for gas exchange, pigments, $\mathrm{H}_{2} \mathrm{O}_{2}$ production, RWC, electrolyte leakage, total soluble proteins, specific leaf weight, and mineral nutrients; and 7-15 replicates for the OJIP transients and the fluorescence parameters. The results are presented using the mean \pm SE of 3-15 replicates. For a given dependent variable or parameter above, significant differences among the means of 10 treatment combinations were tested by a two (species) $\times$ five $(\mathrm{pH}$ levels) factorial ANOVA; the 10 means were compared on a pairwise basis by the Duncan's new multiple range test at $P<0.05$. Linear and nonlinear regression was performed with the corresponding equations from SigmaPlot software (SigmaPlot 10.0, Systat Software Inc., USA).

\section{RESULTS}

\section{Effects of pH on Seedling Growth}

Overall, the pH-2.5 treatment greatly decreased root, stem, leaf, and whole plant DW; pH 3 slightly inhibited seedling growth; $\mathrm{pH} 4$ had almost no influence on seedling growth; and seedling growth reached a maximum at $\mathrm{pH} 5$ (Figures 1, 2). At $\mathrm{pH} 2.5$, many rotted fibrous roots were observed, and the living roots had turned abnormally dark brown (Figures 2A,D). Mottled bleached leaves were found in four $C$. grandis seedlings treated with $\mathrm{pH} 2.5$ (Figure 2B). No seedling death was observed for the two citrus species at each given $\mathrm{pH}$.

\section{Effects of pH on Leaf Gas Exchange, Rubisco Activity, and Pigment Levels}

As shown in Figure 3, leaf $\mathrm{CO}_{2}$ assimilation, stomatal conductance, transpiration, and Rubisco activity were little changed as the $\mathrm{pH}$ decreased from 6 to 3, but they greatly decreased at $\mathrm{pH}$ 2.5. Leaf WUE was lower at $\mathrm{pH} 2.5$ than at $\mathrm{pH}$ 5. All five parameters were similar between the two citrus species at each given $\mathrm{pH}$. Intercellular $\mathrm{CO}_{2}$ concentration did not significantly differ among the 10 treatment combinations, but there was a slight increase observed in the $\mathrm{pH}$ 2.5-treated $C$. grandis leaves.

As shown in Figure 4, leaf $\mathrm{Chl} \mathrm{a,} \mathrm{Chl} \mathrm{b,} \mathrm{Chl} \mathrm{a+b,} \mathrm{and} \mathrm{Car}$ concentrations greatly increased as the $\mathrm{pH}$ increased from 2.5 to 3 , after which they remained unchanged or were only slightly altered with increasing $\mathrm{pH}$. These concentrations did not differ significantly between the two citrus species at $\mathrm{pH} \mathrm{3,4,5}$, and 6 , but they were lower in $C$. sinensis leaves than in C. grandis leaves at $\mathrm{pH}$ 2.5. Moreover, there was little difference in the ratios of leaf $\mathrm{Chl} \mathrm{a/b}$ and $\mathrm{Car} / \mathrm{Chl}$ among the 10 treatment combinations. The only exception was the lower $\mathrm{Car} / \mathrm{Chl}$ ratio in the $\mathrm{pH}$ 2.5-treated C. sinensis leaves when compared with the other nine treatment combinations.

Leaf $\mathrm{CO}_{2}$ assimilation increased with increasing leaf stomatal conductance, the activity of Rubisco, and the concentration of $\mathrm{Chl} \mathrm{a}$, Chl b, or Chl a+b, but it decreased with an increasing intercellular $\mathrm{CO}_{2}$ concentration (Figure 5).

\section{Effects of $\mathrm{pH}$ on $\mathrm{Chl}$ a Fluorescence and Related Parameters}

Our results showed that $\mathrm{pH} 2.5$ caused an increased O-step and P-step in C. sinensis and C. grandis leaves compared with $\mathrm{pH}$ 5, and that the $\mathrm{pH}$ 2.5-treated $C$. sinensis and $C$. grandis leaves had positive $\Delta \mathrm{I}-, \Delta \mathrm{J}-, \Delta \mathrm{K}$-, and $\Delta \mathrm{L}$-bands around $30 \mathrm{~ms}, 2$ $\mathrm{ms}, 300 \mu \mathrm{s}$, and $130 \mu \mathrm{s}$ as compared with the $\mathrm{pH}$ 5-treated leaves, respectively. The $\mathrm{pH} 2.5$-induced alterations of the OJIP transients and the $\Delta \mathrm{I}$ - and $\Delta \mathrm{L}$-bands were greater in the leaves of $C$. grandis than in those of $C$. sinensis. Little, if any, differences were observed in the OJIP transients among the $\mathrm{pH} 3-, 4-$, 5-, and 6-treated leaves (Figure 6).

As shown in Figure 7, the $\mathrm{F}_{\mathrm{o}}, \mathrm{F}_{\mathrm{m}}, \mathrm{M}_{\mathrm{o}}, \mathrm{ABC} / \mathrm{RC}, \mathrm{DI}_{\mathrm{o}} / \mathrm{RC}$, $\mathrm{DI}_{\mathrm{o}} / \mathrm{ABS}, \mathrm{qNP}$, and NPQ all increased, and whereas the $\mathrm{F}_{\mathrm{v}} / \mathrm{F}_{\mathrm{m}}$, $\mathrm{ET}_{\mathrm{o}} / \mathrm{ABS}, \mathrm{RE}_{\mathrm{o}} / \mathrm{ABS}, \mathrm{P}_{2 \mathrm{G}}, \mathrm{PI}_{\text {tot,abs }}, \mathrm{qP}, \mathrm{F}_{\mathrm{m}}{ }^{\prime} / \mathrm{F}_{\mathrm{v}}{ }^{\prime}, \Phi_{\mathrm{PSII}}$, and ETR all decreased as the $\mathrm{pH}$ increased from 2.5 to 3 , with further increasing $\mathrm{pH}$ there was hardly any change in all these parameters. Nonetheless, the $\mathrm{F}_{\mathrm{v}}$ did not greatly change in response to $\mathrm{pH}$. All these parameters were similar between the two citrus species at $\mathrm{pH} 3,4,5$, or 6 , but the $\mathrm{pH} 2.5$-induced changes in $F_{o}, F_{v}, F_{m}, M_{o}, A B C / R C, D_{o} / R C, D I_{o} / R C, F_{v} / F_{m}$, $\mathrm{RE}_{\mathrm{o}} / \mathrm{ABS}, \mathrm{P}_{2 \mathrm{G}}, \mathrm{PI}_{\text {tot,abs }}$, and ETR were slightly greater in $C$. grandis than in C. sinensis leaves.

Leaf $\mathrm{CO}_{2}$ assimilation decreased with increasing $\mathrm{F}_{\mathrm{o}}, \mathrm{F}_{\mathrm{m}}$, $\mathrm{F}_{\mathrm{v}}, \mathrm{M}_{\mathrm{o}}, \mathrm{ABC} / \mathrm{RC}, \mathrm{DI}_{\mathrm{o}} / \mathrm{RC}, \mathrm{DI}_{\mathrm{o}} / \mathrm{ABS}, \mathrm{qNP}$, or NPQ, whereas it increased with increasing $\mathrm{F}_{\mathrm{v}} / \mathrm{F}_{\mathrm{m}}, \mathrm{ET}_{\mathrm{o}} / \mathrm{ABS}, \mathrm{RE}_{\mathrm{o}} / \mathrm{ABS}, \mathrm{P}_{2 G}$, $\mathrm{PI}_{\text {tot,abs }}, \mathrm{qP}, \mathrm{F}_{\mathrm{m}}{ }^{\prime} / \mathrm{F}_{\mathrm{v}}{ }^{\prime}, \Phi_{\mathrm{PSII}}$, or ETR (Figure 8).

\section{Effects of pH on RWC, $\mathrm{H}_{2} \mathrm{O}_{2}$ Production, Electron Leakage, Total Soluble Proteins in Roots and Leaves and Specific Leaf Weight}

Both $\mathrm{pH} 2.5$ and 3 decreased the root RWC, while only $\mathrm{pH} 2.5$ lowered the leaf RWC. Root and leaf RWCs were similar between the two citrus species at each given $\mathrm{pH}$ (Figures 9A,F).

Both $\mathrm{pH} 2.5$ and 3 increased the root $\mathrm{H}_{2} \mathrm{O}_{2}$ production, while only pH 2.5 enhanced the leaf $\mathrm{H}_{2} \mathrm{O}_{2}$ production. Root (Leaf) $\mathrm{H}_{2} \mathrm{O}_{2}$ production was significantly higher in $C$. grandis than in C. sinensis at $\mathrm{pH} 2.5(2.5,3,4$, and 6$)$, but similar between the citrus species at pH 3-6 (pH 5; Figures 9B,G).

Root and leaf electrolyte leakage increased as the $\mathrm{pH}$ increased from 2.5 to 3 , after which leakage remained relatively stable under increasing $\mathrm{pH}$. Root and leaf electrolyte leakage was higher in $C$. 


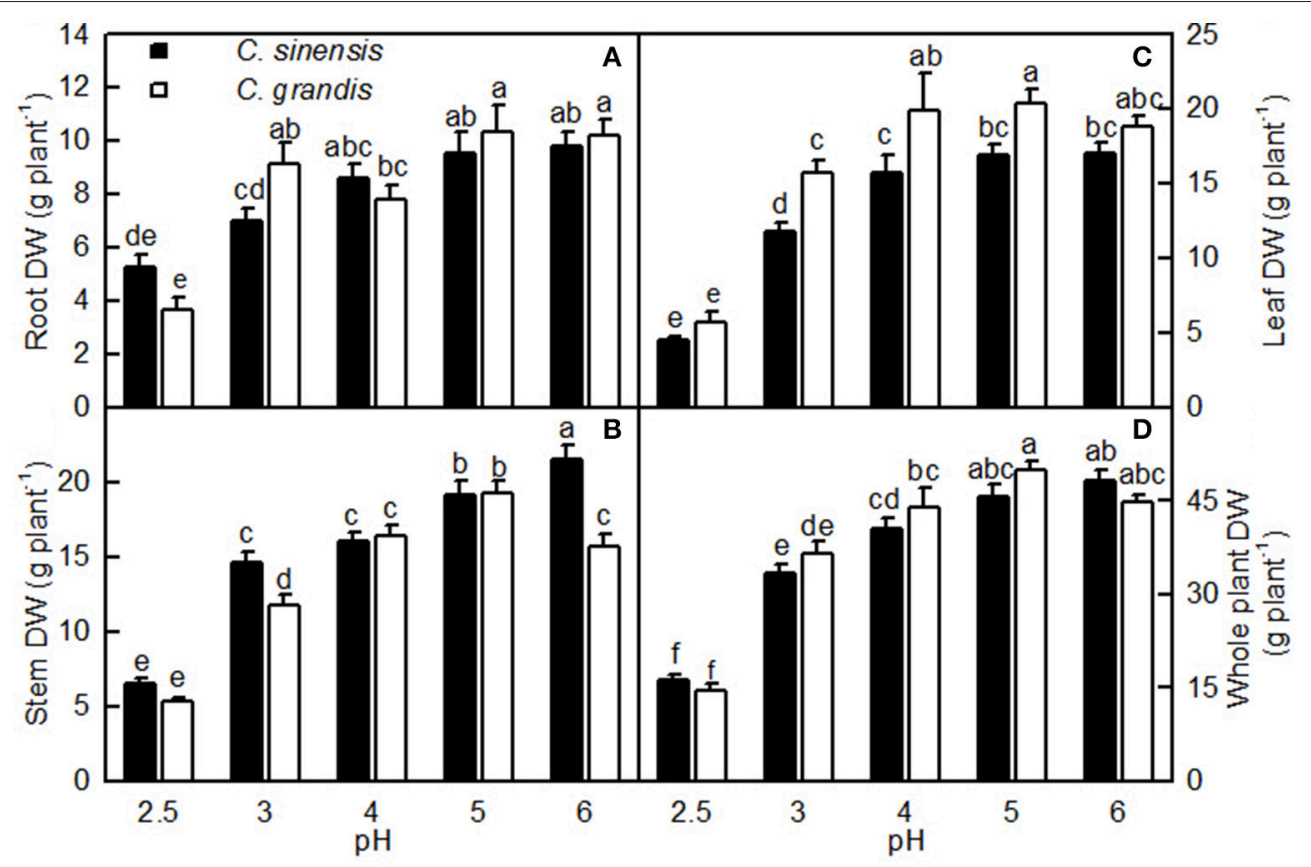

FIGURE 1 | Effects of pH on root (A), stem (B), leaf (C), and whole plant (D) DW of Citrus sinensis and Citrus grandis seedlings. Bars represent means \pm $\mathrm{SE}(n=10)$. Differences among the 10 treatments were analyzed by two (species) $\times$ five $(\mathrm{pH})$ factorial ANOVA. Different letters above the bars indicate a significant difference at $P<0.05$.

grandis than in C. sinensis at $\mathrm{pH} 2.5$, but it was similar between the citrus species at $\mathrm{pH} 3-6$ (Figures 9C, H).

For C. grandis, the total soluble protein level in roots increased as the $\mathrm{pH}$ increased from 2.5 to 4 , after which it remained unchanged with increasing $\mathrm{pH}$. For $C$. sinensis, the total soluble protein level in roots was lowest at $\mathrm{pH} 2.5$, intermediate at $\mathrm{pH}$ 3 and 6, and highest at $\mathrm{pH} 4$ and 5 . The total soluble protein level in leaves of the two citrus species increased as the $\mathrm{pH}$ increased from 2.5 to 3 , but these levels were little changed with increasing $\mathrm{pH}$. The total soluble protein levels in roots and leaves were higher in C. grandis than in C. sinensis, or they were statistically similar between the two species at each given $\mathrm{pH}$ (Figures 9D,I).

The specific leaf weight was decreased at $\mathrm{pH} 2.5$ and it was higher in C. grandis than in C. sinensis, or it was similar between the two species at each given $\mathrm{pH}$ irrespective of how the data were expressed (Figures 9E,J).

Leaf $\mathrm{CO}_{2}$ assimilation decreased with increasing root and leaf $\mathrm{H}_{2} \mathrm{O}_{2}$ production or electrolyte leakage, but it increased with increasing root and leaf RWC (Figure 10).

\section{Effects of pH on Element Concentrations, Uptake, and Distributions}

The leaf $\mathrm{N}$ level was lower at $\mathrm{pH} 2.5$ than at $\mathrm{pH} 3-6$, but the stem and root $\mathrm{N}$ levels remained little changed over the range of $\mathrm{pH}$ 2.5-6. The $\mathrm{P}$ level in C. grandis (C. sinensis) leaves and stems increased as the $\mathrm{pH}$ increased from 2.5 to 4 (3), but it went unchanged with increasing $\mathrm{pH}$. The root $\mathrm{P}$ level increased as the $\mathrm{pH}$ increased from 2.5 to 5 , but it then kept stable with increasing $\mathrm{pH}$. The $\mathrm{K}$ concentration in the $C$. sinensis leaves and stems and in the C. grandis leaves displayed little change in the range of $\mathrm{pH}$ 2.5-6; however, the $\mathrm{K}$ level in the $C$. sinensis roots and in the $C$. grandis stems and leaves was lower at $\mathrm{pH} 2.5$ than at pH 3-6. Generally viewed, the Ca levels in the leaves, stems, and roots all increased as the $\mathrm{pH}$ increased from 2.5 to 4 , after which they were relatively stable with increasing $\mathrm{pH}$. The $\mathrm{Mg}$ level in the C. grandis leaves and stems and in the C. sinensis leaves decreased with decreasing $\mathrm{pH}$, but the $\mathrm{Mg}$ level in the $C$. sinensis stems did not change in response to $\mathrm{pH}$. The $\mathrm{Mg}$ level in the $C$. sinensis roots was reduced at $\mathrm{pH} 2.5,3$, and 4, but especially at $\mathrm{pH} 2.5$ and 3, while its level in the C. grandis roots was elevated at $\mathrm{pH} 2.5$ and $\mathrm{pH} 3$, though especially at $\mathrm{pH} 3$. Leaf and root $\mathrm{S}$ decreased with increasing $\mathrm{pH}$, while the stem $\mathrm{S}$ level was higher at $\mathrm{pH} 2.5$ than at the other $\mathrm{pH}$ treatments. Leaf $\mathrm{P}, \mathrm{K}, \mathrm{Ca}$, and $\mathrm{S}$, stem $\mathrm{P}, \mathrm{K}$, and $\mathrm{S}$, and root $\mathrm{P}$ levels were all higher in $C$. sinensis than in $C$. grandis seedlings; or similar between the two citrus species at each given $\mathrm{pH}$. Conversely, the leaf $\mathrm{Mg}$, stem $\mathrm{Ca}$ and $\mathrm{Mg}$, and root $\mathrm{N}, \mathrm{K}, \mathrm{Ca}$, $\mathrm{Mg}$, and $\mathrm{S}$ levels were all lower in C. sinensis than in C. grandis seedlings, or they were similar between the two citrus species at each given $\mathrm{pH}$ (Figure 11).

The Fe level in the C. grandis leaves was lower at $\mathrm{pH} 2.5$ and 3 than at pH 4-6, while the Fe level in the $C$. sinensis leaves did not differ among the five $\mathrm{pH}$ treatments. The Fe level in the C. sinensis (C. grandis) stems increased as the $\mathrm{pH}$ increased from 2.5 to 3 (4), but it then kept relatively stable with increasing $\mathrm{pH}$, though it decreased at $\mathrm{pH}$ 6. The root Fe concentration decreased with increasing $\mathrm{pH}$. Leaf and stem $\mathrm{Mn}$ levels decreased with increasing $\mathrm{pH}$. The root $\mathrm{Mn}$ level increased as the $\mathrm{pH}$ decreased from 6 

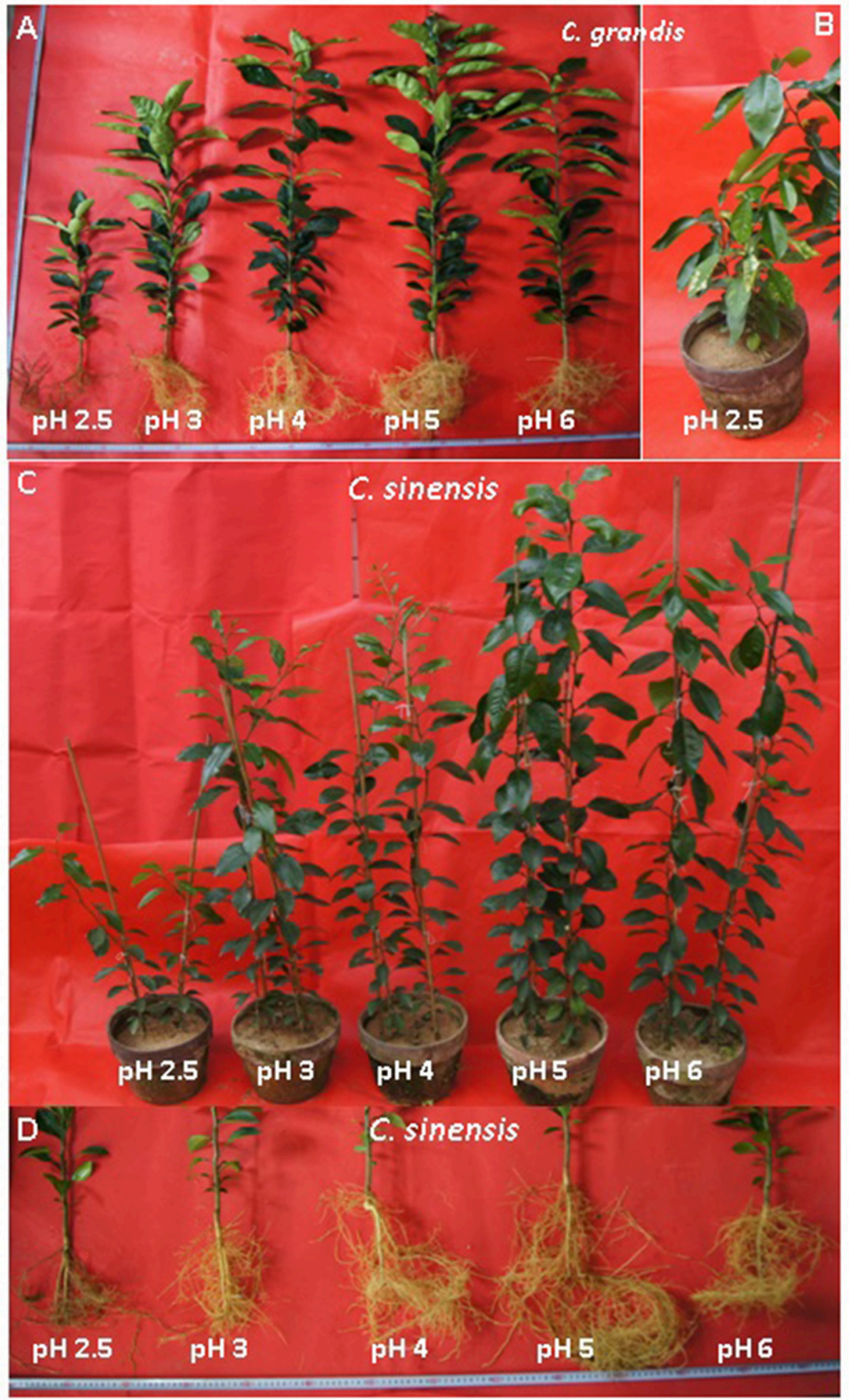

FIGURE 2 | Effects of pH on the growth of Citrus grandis $(\mathrm{A}, \mathrm{B})$ and Citrus sinensis (C,D) seedlings.

to 3 , then it decreased or went unchanged at $\mathrm{pH}$ 2.5. Leaf $\mathrm{B}$ concentration in the two citrus species was decreased only at $\mathrm{pH}$ 2.5. The B level in the C. sinensis (C. grandis) stems increased as the $\mathrm{pH}$ increased from 2.5 to 4 (3), but then it went unchanged with increasing $\mathrm{pH}$, though it decreased at $\mathrm{pH}$ 6. Although the root $\mathrm{B}$ concentration increased as the $\mathrm{pH}$ increased from 2.5 


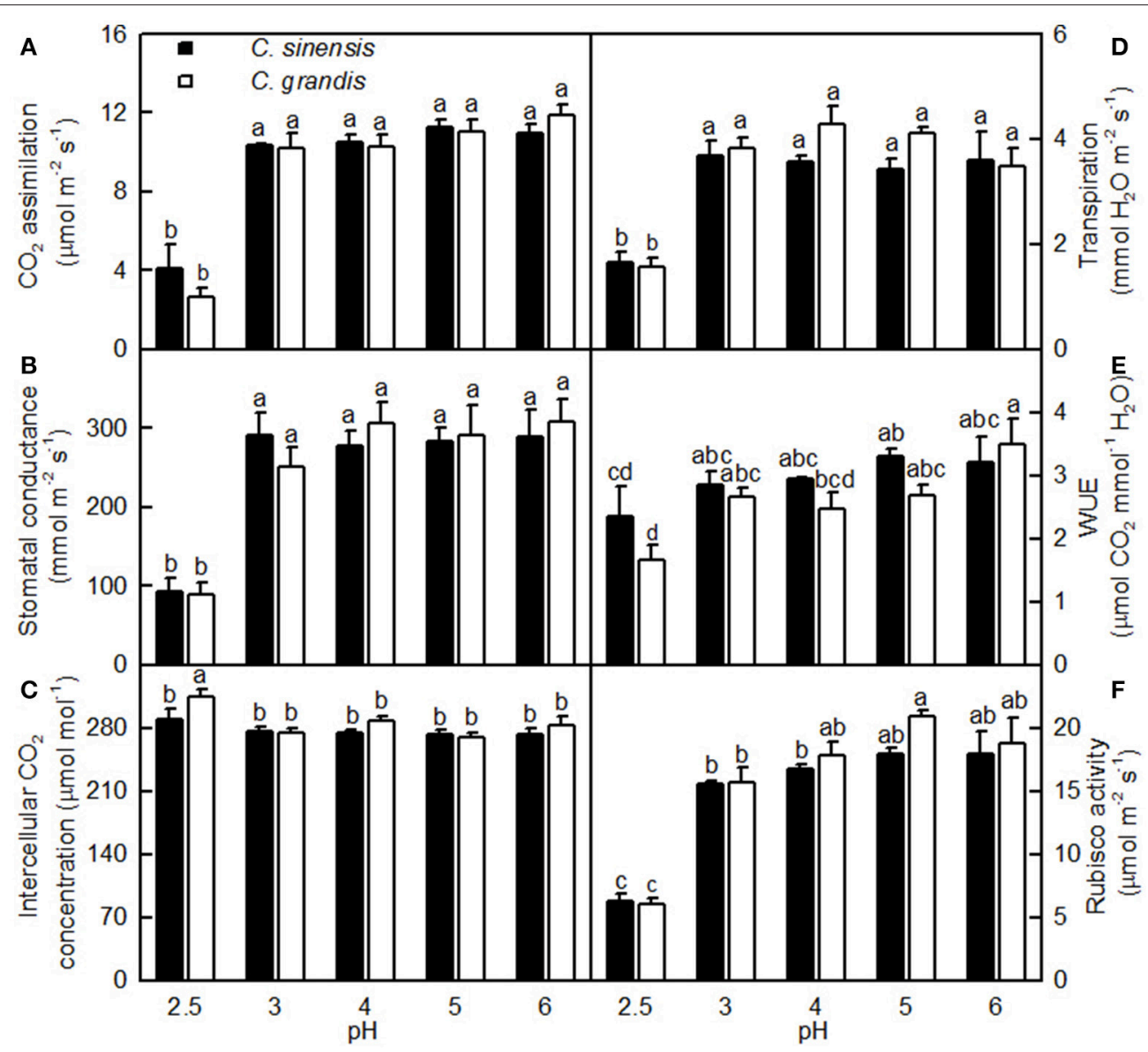

FIGURE 3 | Effects of $\mathrm{pH}$ on $\mathrm{CO}_{2}$ assimilation (A), stomatal conductance (B), intercellular $\mathrm{CO}_{2}$ concentration (C), transpiration rate (D), water-use efficiency (WUE, E), and Rubisco activity (F) in Citrus sinensis and Citrus grandis leaves. Bars represent means \pm SE $(n=3$ for Rubisco or $n=4$ for the other parameters). Differences among the 10 treatments were analyzed by two (species) $\times$ five $(\mathrm{pH})$ factorial ANOVA. Different letters above the bars indicate a significant difference at $P<0.05$.

to 5, it decreased at $\mathrm{pH}$ 6. The $\mathrm{Cu}$ level in the C. grandis leaves increased as the $\mathrm{pH}$ decreased from 6 to 4 , after which it was little changed with decreasing $\mathrm{pH}$; the $\mathrm{Cu}$ level in the $C$. sinensis leaves was highest at $\mathrm{pH} 5$ and lowest at $\mathrm{pH}$ 6. Root $\mathrm{Cu}$ level in the two citrus species decreased as the $\mathrm{pH}$ increased from 2.5 to 4 , but it then remained stable with increasing $\mathrm{pH}$. The $\mathrm{Zn}$ level in the $C$. sinensis leaves and stems were lower at $\mathrm{pH} 5$ and 6 than at $\mathrm{pH} 2.5,3$, and 4 , while its level in the $C$. grandis leaves and stems were lower at $\mathrm{pH} 6$ than at $\mathrm{pH} 2.5-5$. The $\mathrm{Zn}$ level in the C. sinensis roots increased as the $\mathrm{pH}$ decreased from 6 to 3 , but it then decreased at $\mathrm{pH} 2.5$; the $\mathrm{Zn}$ level in C. grandis roots was highest at $\mathrm{pH} 3$ and lowest at $\mathrm{pH}$ 6. Generally viewed, the leaf Fe, $\mathrm{Mn}, \mathrm{B}$ and $\mathrm{Cu}$, stem $\mathrm{Fe}, \mathrm{Mn}, \mathrm{B}, \mathrm{Cu}$ and $\mathrm{Zn}$, root $\mathrm{Fe}, \mathrm{B}, \mathrm{Mn}$, and $\mathrm{Zn}$ concentrations all were higher in C. grandis than in C. sinensis, or they were similar between the two citrus species at each given $\mathrm{pH}$. The exceptions to this generalization were that the $\mathrm{Mn}(\mathrm{Cu})$ level was higher in C. sinensis than in C. grandis leaves at pH 2.5 (5), and the Fe level was higher in C. sinensis than in C. grandis stems at $\mathrm{pH}$ 2.5. By contrast, the leaf $\mathrm{Zn}$ and root $\mathrm{Cu}$ concentrations were higher in the $C$. sinensis than in those of $C$. grandis, or they were similar between the two citrus species at $\mathrm{pH} 2.5-5$, albeit leaf $\mathrm{Zn}$ lower was lower in the C. sinensis vs. C. grandis at $\mathrm{pH} 6$ (Figure 12).

For C. sinensis, the $\mathrm{N}, \mathrm{P}, \mathrm{K}, \mathrm{Ca}, \mathrm{Mg}$, and $\mathrm{B}$ uptake per plant increased as the $\mathrm{pH}$ increased from 2.5 to 5 , then continued to rise or kept unchanged with increasing $\mathrm{pH}$; For C. grandis, these elemental uptake per plant increased as the $\mathrm{pH}$ increased from 2.5 to 5 , but then it went unchanged or decreased with increasing $\mathrm{pH}$. The Mn uptake per plant in the two citrus species increased as the $\mathrm{pH}$ increased from 2.5 to 3 , but it then decreased with increasing $\mathrm{pH}$. Treatment with $\mathrm{pH} 2.5$ decreased the $\mathrm{S}, \mathrm{Fe}, \mathrm{Cu}$, and $\mathrm{Zn}$ uptake per plant compared with the corresponding uptake at $\mathrm{pH}$ 5 (Figures 13A-F,M-Q).

Compared with $\mathrm{pH}$ 5, treatment with $\mathrm{pH} 2.5$ decreased the $\mathrm{N}, \mathrm{P}, \mathrm{K}, \mathrm{Ca}, \mathrm{Mg}$, and $\mathrm{B}$ uptake per root $\mathrm{DW}$, whereas it increased the $\mathrm{S}, \mathrm{Fe}, \mathrm{Mn}$, and $\mathrm{Zn}$ uptake per root $\mathrm{DW}$; however, $\mathrm{pH} 2.5$ did not influence $\mathrm{Cu}$ and $\mathrm{Zn}$ uptake per root $\mathrm{DW}$ (Figures 13G-L,R-V).

Leaf $\mathrm{CO}_{2}$ assimilation increased with increasing leaf $\mathrm{N}, \mathrm{P}, \mathrm{Ca}$, $\mathrm{Mg}, \mathrm{Fe}$, or B, whereas it decreased with increasing leaf $\mathrm{S}, \mathrm{Mn}, \mathrm{Cu}$, or $\mathrm{Zn}$-it did not display a significant relationship with leaf $\mathrm{K}$. Except for the Mn uptake per plant, the leaf $\mathrm{CO}_{2}$ assimilation 


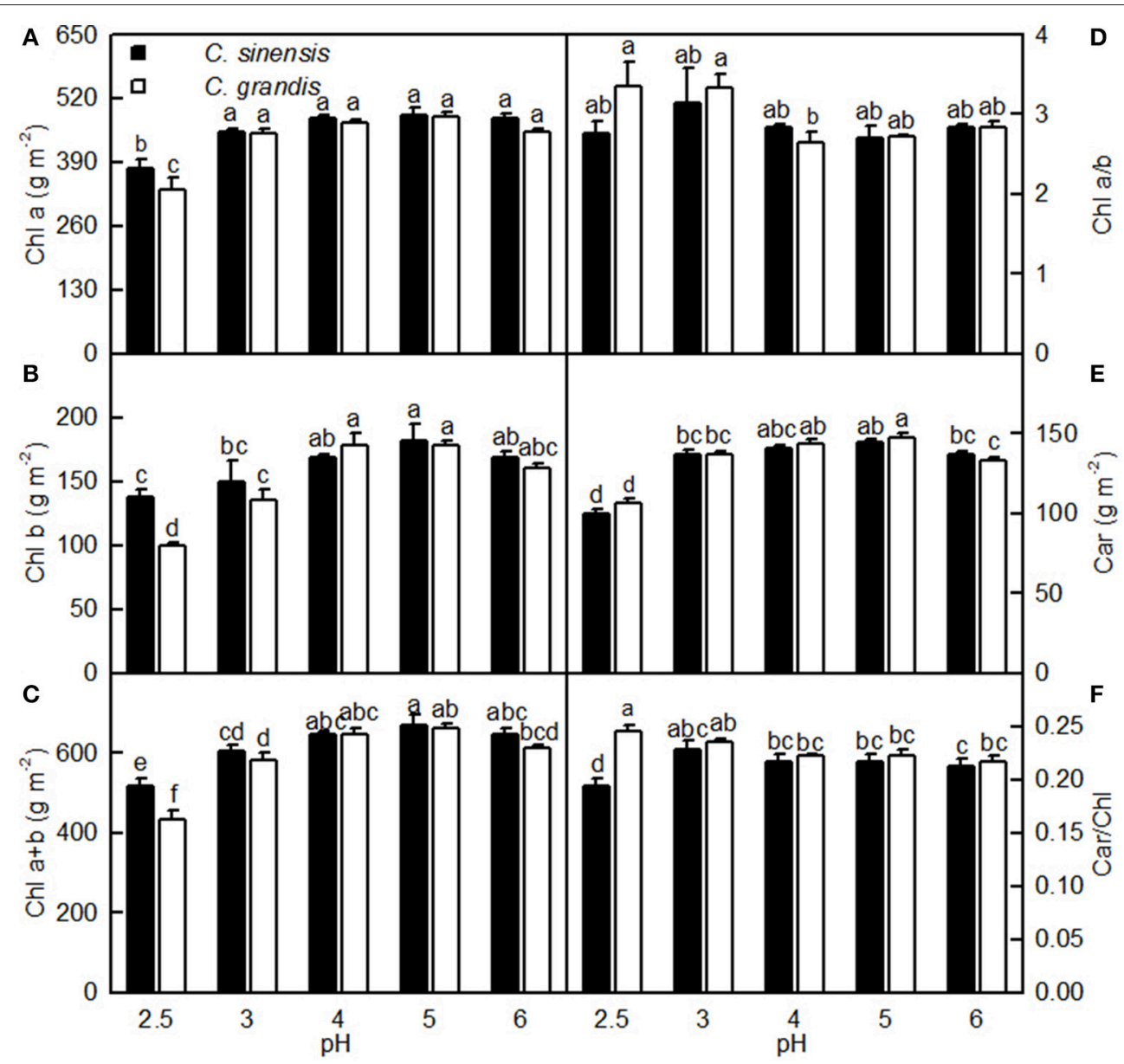

FIGURE 4 | Effects of pH on Chl a (A), Chl b (B), Chl a+b (C), Chl a/b (D), Car (E), and Car/Chl (F) in C. sinensis and C. grandis leaves. Bars represent means \pm SE $(n=4)$. Differences among the 10 treatments were analyzed by two (species) $\times$ five $(\mathrm{pH})$ factorial ANOVA. Different letters above the bars indicate a significant difference at $P<0.05$.

increased with increasing uptake per plant of the other elements (Figure 14).

Compared with $\mathrm{pH} 5$, treatment with $\mathrm{pH} 2.5$ lowered all the element distributions in the $C$. sinensis leaves and the $\mathrm{S}, \mathrm{Fe}$, and $\mathrm{Cu}$ distributions in the $C$. sinensis stems; it increased, or did not affect, the 11 element distributions in the $C$. sinensis roots and the $\mathrm{N}, \mathrm{P}, \mathrm{K}, \mathrm{Mg}, \mathrm{Mn}, \mathrm{B}$, and $\mathrm{Zn}$ distributions in the $\mathrm{C}$. sinensis stems. Compared with $\mathrm{pH} 5, \mathrm{pH} 2.5$ decreased or did not influence the $\mathrm{K}$ distribution in the stems and roots and the distributions of the other 10 elements in the leaves and stems; $\mathrm{pH} 2.5$ increased or did not influence the $\mathrm{K}$ distribution in the leaves and the distributions of the other 10 elements in the roots of the C. grandis seedlings (Figures S1, S2).

\section{DISCUSSION}

Low $\mathrm{pH}$ very often affects the uptake of nutrients and water by plants (Kamaluddin and Zwiazek, 2004; Bian et al., 2013). As expected, $\mathrm{pH} 2.5$ lowered the water uptake in citrus, as indicated by the reduced root and leaf RWC (Figures 9A,F). This result is supported by the finding that the water content was decreased in low pH-treated Eucalyptus roots, stems, and leaves (Yang M. et al., 2011). As shown in Figures 9-13, the uptakes of mineral nutrients were greatly altered at $\mathrm{pH} 2.5$. Compared with $\mathrm{pH} 5$, the pH 2.5 lowered N, P, K, Ca, and Mg uptake per plant or root DW, and the $\mathrm{S}$ uptake per plant. Low $\mathrm{pH}$ (4.0 relative to 7.0 ) induced decreases in the $\mathrm{N}, \mathrm{P}, \mathrm{K}, \mathrm{Ca}$, and $\mathrm{Mg}$ uptake per plant in $\mathrm{V}$. faba (Schubert et al., 1990). Similarly, Malkanthi et al. (1995) observed that a pH 3.8 (relative to 5.5) decreased the $\mathrm{K}, \mathrm{Ca}$, and $\mathrm{Mg}$ uptake per plant in wheat, barley, and chili, and likewise in cowpea for $\mathrm{Ca}$ and $\mathrm{Mg}$ uptake per plant. However, the uptake of $\mathrm{N}, \mathrm{P}, \mathrm{K}, \mathrm{Ca}$, and $\mathrm{Mg}$ in sago palm seedlings was not changed in the range of pH 3.6-5.7 over a 4.5-month period (Anugoolprasert et al., 2012). Thus, it appears that the effects of low $\mathrm{pH}$ on macronutrient uptake per plant depend on both the plant species identity and the $\mathrm{H}^{+}$strength (i.e., $\mathrm{pH}$ value).

On the whole, apart from a few exceptions, the concentrations of $\mathrm{N}, \mathrm{P}, \mathrm{K}, \mathrm{Ca}$, and $\mathrm{Mg}$ were decreased in the $\mathrm{pH}$ 2.5-treated $C$. grandis and C. sinensis roots, stems, and leaves (Figure 11). This 

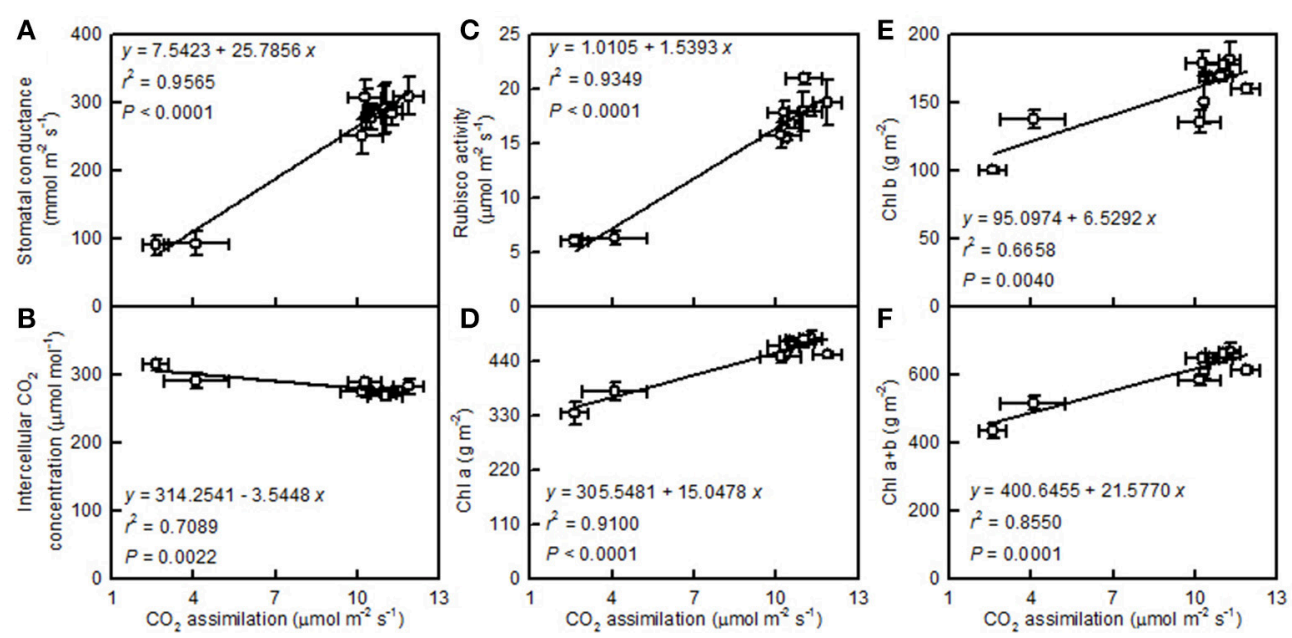

FIGURE 5 | Leaf $\mathrm{CO}_{2}$ assimilation in relation to stomatal conductance (A), intercellular $\mathrm{CO}_{2}$ concentration (B), Rubisco activity (C), Chl a (D), Chl b (E), and $\mathbf{C h l} \mathbf{a}+\mathbf{b} \mathbf{( F )}$. Points represent means $\pm \mathrm{SE}$ for the independent variable $(n=4)$ and the dependent variables $(n=3$ or 4$)$. Data for $\mathrm{CO}_{2}$ assimilation, stomatal conductance, intercellular $\mathrm{CO}_{2}$ concentration, and Rubisco activity are from Figure 3. Data for $\mathrm{Chl} \mathrm{a,} \mathrm{Chl} \mathrm{b,} \mathrm{and} \mathrm{Chl} \mathrm{a+b} \mathrm{are} \mathrm{from} \mathrm{Figure} \mathrm{4.} \mathrm{Data} \mathrm{for} \mathrm{the} \mathrm{two} \mathrm{citrus}$ species were pooled together.

agrees with the report that $\mathrm{pH} 3$ decreased $\mathrm{Ca}$ and $\mathrm{Mg}$ levels in Picea abies roots and needles (George et al., 2012); that P, K, and $\mathrm{Mg}$ levels were lowered in the low $\mathrm{pH}$-treated $V$. faba roots and shoots (Schubert et al., 1990); that the levels of $\mathrm{K}, \mathrm{Ca}$, and $\mathrm{Mg}$ in the roots and tops of wheat, barley, and chili were lower at $\mathrm{pH} 3.8$ than at pH 5.7 (Malkanthi et al., 1995); and that P and Ca levels in pummelo leaves increased linearly with increasing soil $\mathrm{pH}$ ( $\mathrm{Li}$ et al., 2015). However, the levels of N, P, K, Ca, and Mg in the roots, leaflets, petioles, and whole plant of sago palm seedlings did not differ among $\mathrm{pH}$ 3.6, 4.5, and 5.7 (Anugoolprasert et al., 2012). The concentrations of $\mathrm{N}, \mathrm{P}, \mathrm{K}, \mathrm{Ca}$, and Mg might have been reduced in sago palm seedlings if the $\mathrm{pH}$ was lower than $\mathrm{pH}$ 3.6, because the concentration of $\mathrm{N}, \mathrm{P}, \mathrm{K}, \mathrm{Ca}$, and $\mathrm{Mg}$ in citrus roots, stems, and leaves were greatly reduced at $\mathrm{pH} 2.5$ but little affected at $\mathrm{pH} 4$ relative to $\mathrm{pH} 5$ (Figure 11). In contrast, the $\mathrm{S}$ level was increased in the low $\mathrm{pH}$-treated C. grandis and C. sinensis roots, stems, and leaves (Figures 11F,L,R), which is consistent with the finding that the $\mathrm{S}$ concentration in the tops of ginger, maize, wheat, French bean, and tomato plants was higher at $\mathrm{pH} 3.3$ than at pH 4.0 (Islam et al., 1980).

So far, however, there is little published information available on the effects of low $\mathrm{pH}$ on plant micronutrients. $\mathrm{H}^{+}$-toxicity is thought to inhibit the uptake of cations (George et al., 2012). However, treatment with $\mathrm{pH} 2.5$ did not lower $\mathrm{Fe}, \mathrm{Cu}, \mathrm{Mn}$, and $\mathrm{Zn}$ uptake per root DW in the two citrus species, or the Mn uptake per plant in C. sinensis, when compared with $\mathrm{pH}$ 5 (Figures $\mathbf{1 3 N}, \mathbf{R}, \mathbf{S}, \mathbf{U}, \mathbf{V}$ ). This result may be related to the insensitivity of citrus plants to acidic soils, as reported previously by Yuda and Okamoto (1965). Interestingly, the B uptake per plant or per root DW was reduced by a low $\mathrm{pH}$ (Figures 130,T). This result is supported by a work showing that $\mathrm{B}$ could alleviate low $\mathrm{pH}$-induced damage in Arabidopsis roots (Koyama et al., 2001).
The $\mathrm{Fe}, \mathrm{Mn}, \mathrm{Cu}$, and $\mathrm{Zn}$ concentrations in the C. grandis and C. sinensis roots, stems, and leaves were all higher at $\mathrm{pH} 2.5$ than at $\mathrm{pH} \mathrm{5}$, or they were similar between the two treatments, though there was a lower level of $\mathrm{Fe}$ detected in the C. grandis leaves at $\mathrm{pH} 2.5$ than at $\mathrm{pH} 5$ (Figures 12A,B,D-G,I-L,N-Q). The observed higher Fe, Mn, $\mathrm{Cu}$, and $\mathrm{Zn}$ concentrations in the $\mathrm{pH} 2.5$-treated C. grandis and C. sinensis roots, stems, and leaves might be associated with a reduced dilution due to decreased growth (Figure 1) and with higher uptake per root DW (Figures 13R,S,U,V). As shown in Figures 12A,D,F,I,K,N, the root $\mathrm{Fe}$ and $\mathrm{Cu}$ concentrations were higher at $\mathrm{pH} 2.5$ than those at the other treatment levels of $\mathrm{pH}$, while no such results were observed for the leaf and stem $\mathrm{Fe}$ and $\mathrm{Cu}$ concentrations; this may be explained by the increased $\mathrm{Fe}$ and $\mathrm{Cu}$ distributions in the roots, and the decreased or unchanged $\mathrm{Fe}$ and $\mathrm{Cu}$ distributions in the leaves and stems, at $\mathrm{pH} 2.5$ (Figures S2A,D,F,I,K,N). By contrast, the $\mathrm{B}$ level was decreased in the $\mathrm{pH}$ 2.5-treated C. grandis and C. sinensis roots, stems, and leaves (Figures 12C, $\mathbf{H}, \mathbf{M}$ ) likely due to the decreased $\mathrm{B}$ uptake per plant or root DW (Figures 130,T).

In this experiment, many of the fibrous roots became rotten and the living roots turned abnormally dark brown when exposed to $\mathrm{pH} 2.5$ (Figures 2A,D). Thus, it is reasonable to presume that $\mathrm{H}^{+}$-toxicity may directly damage citrus roots, thus affecting the uptake of vital mineral nutrients and water.

Our results showed that $\mathrm{pH} 2.5$ lowered the root, stem, leaf, and whole plant DW (Figures 1, 2). The low $\mathrm{pH}-$ induced poor growth of citrus seedlings may be due to the combined interplay of direct $\mathrm{H}^{+}$-toxicity-as shown by the damaged roots (Figures 2A,D)-deficiencies of macronutrients-as indicated by the decreased $\mathrm{N}, \mathrm{P}, \mathrm{K}, \mathrm{Ca}$, and $\mathrm{Mg}$ concentrations (Figures 11A-E) - and uptake per plant 

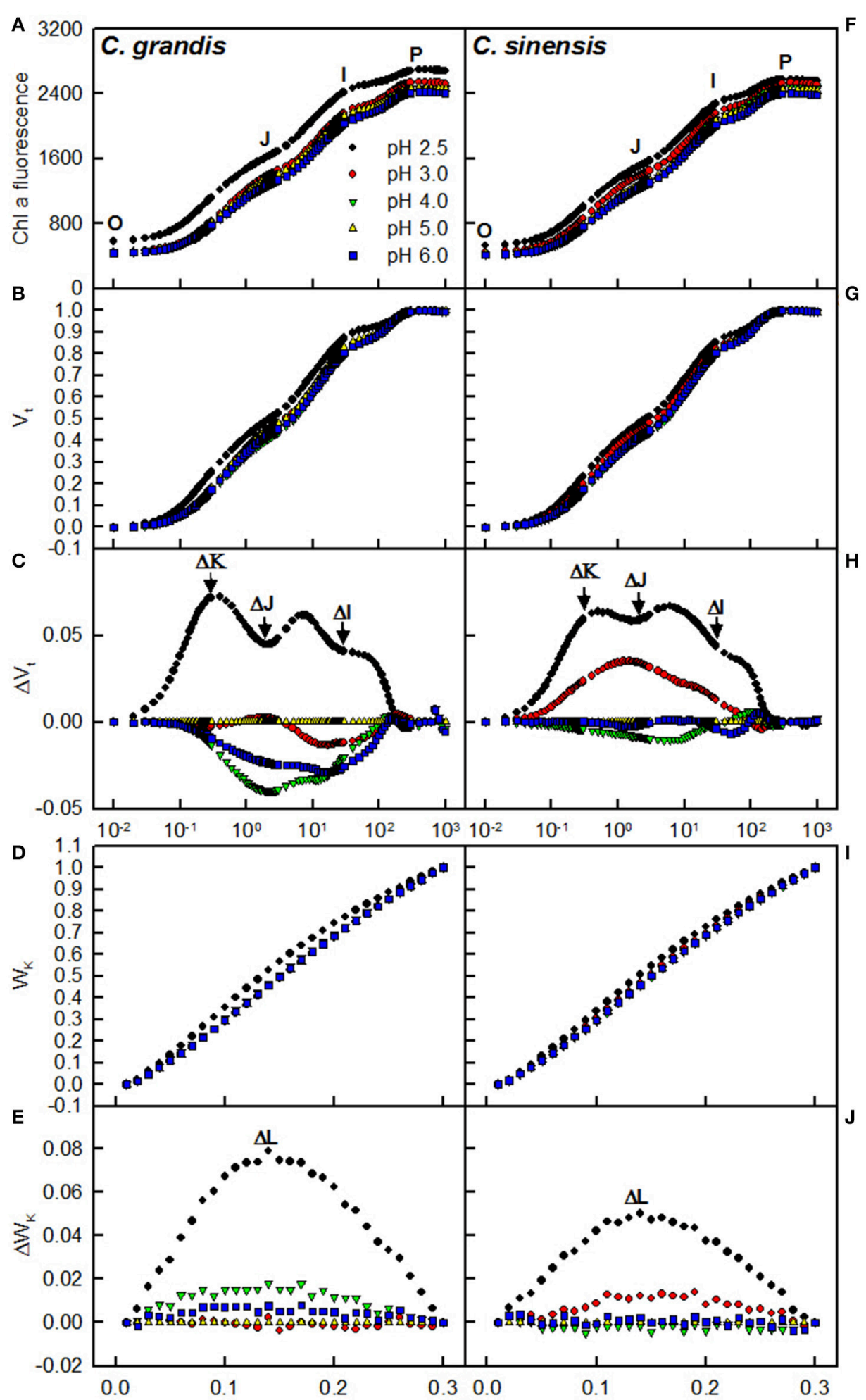

FIGURE 6 | Effects of pH on the mean chlorophyll a fluorescence (OJIP) transients (A,F) and the different expressions derived from the transients in dark-adapted leaves: $(B, G)$ between $F_{o}$ and $F_{m}: V_{t}=\left(F_{t}-F_{o}\right) /\left(F_{m}-F_{o}\right)$ and $(C, H)$ the differences of the five samples to the reference sample treated with pH $5.0\left(\Delta V_{t}\right) ;(D, I)$ between $F_{o}$ and $F_{300 \mu s}: W_{K}=\left(F_{t}-F_{o}\right) /\left(F_{300 \mu}-F_{o}\right)$ and $(E, J)$ the differences of the five samples to the reference sample treated with $\mathbf{p H} \mathbf{5 . 0}\left(\Delta \mathbf{W}_{\mathbf{K}}\right)$. Each point was the mean of 8-15 replicates. 


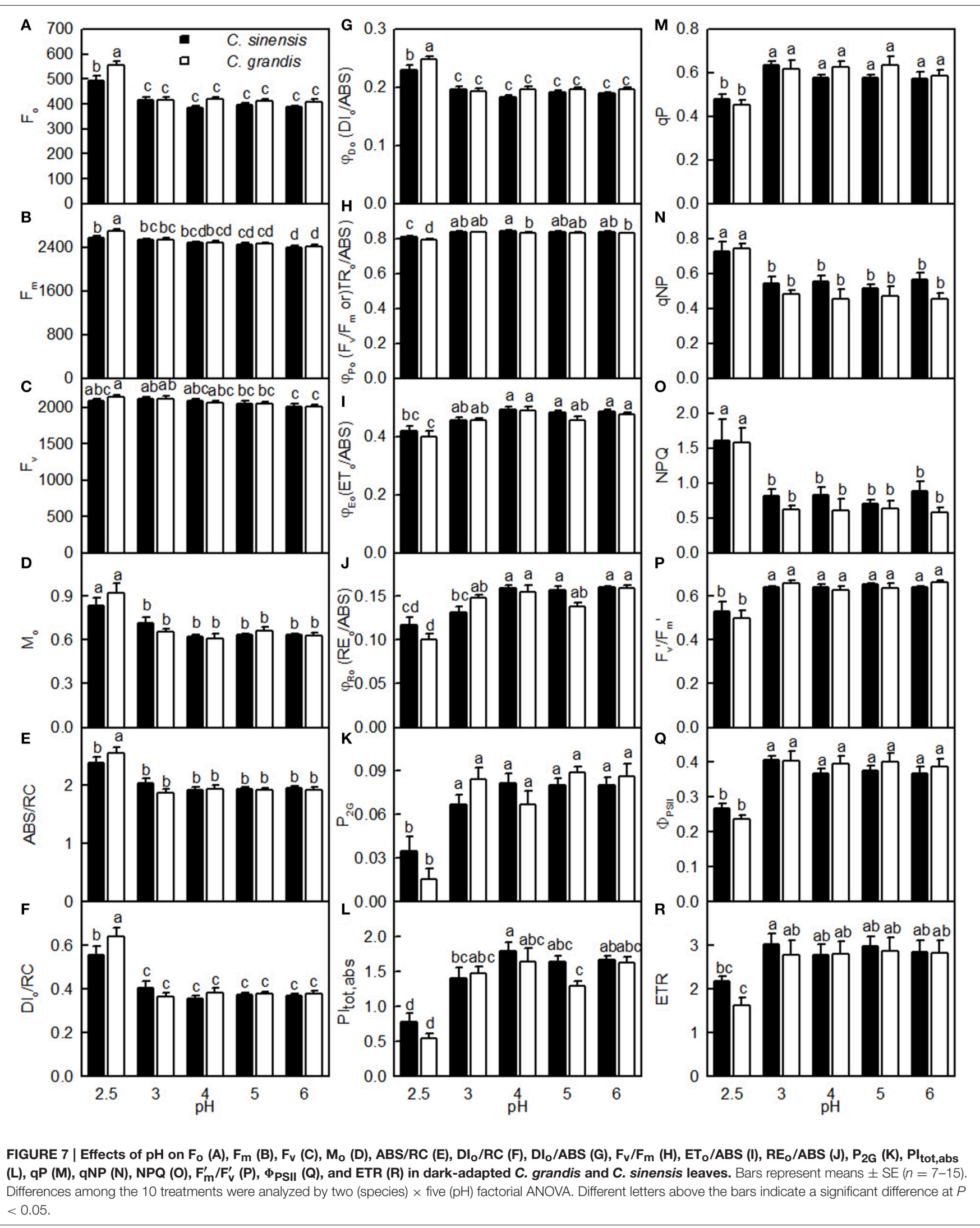




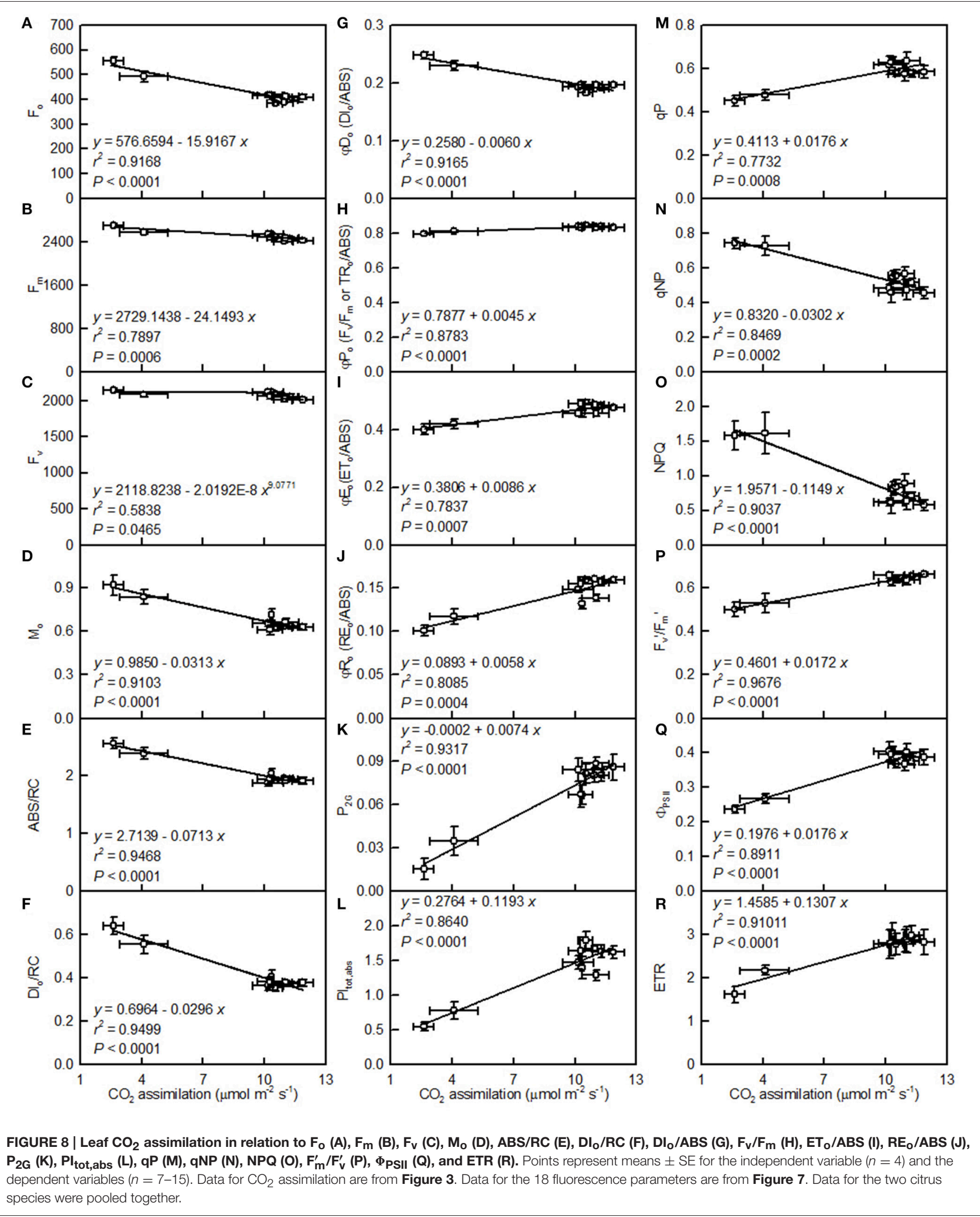




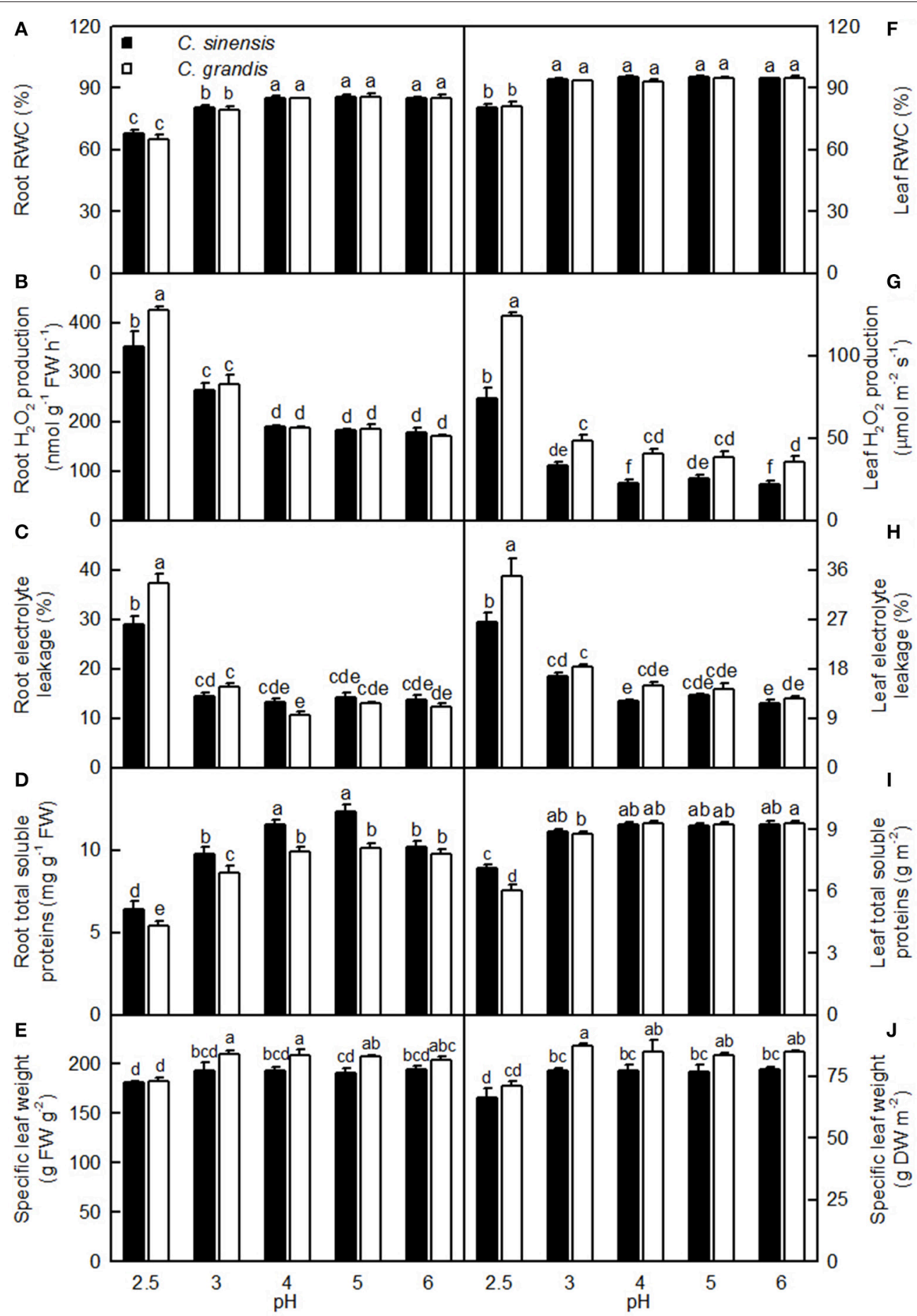

FIGURE 9 | Effects of $\mathrm{pH}$ on root (A-D) and leaf (F-I) relative water content (RWC, $A, F), \mathrm{H}_{2} \mathrm{O}_{2}$ production (B,G), electrolyte leakage (C,H), concentrations of total soluble proteins (D,I), and specific leaf weight expressed on a fresh weight (FW, E) or dry weight (DW, J) basis in the $C$. sinensis and C. grandis seedlings. Bars represent means \pm SE $(n=4)$. Differences among the 10 treatments were analyzed by two $($ species $) \times$ five $(p H)$ factorial ANOVA. Different letters above the bars indicate a significant difference at $P<0.05$.

or root DW (Figures 13A-E,G-K), and the decreased water uptake-as indicated by the decreased root and leaf RWC (Figures 9A,F).
In spite of the reduced growth at $\mathrm{pH} 2.5$, no seedling deaths occurred in the two citrus species at each given $\mathrm{pH}$ during the entire experiment. Similar results have been obtained for several 

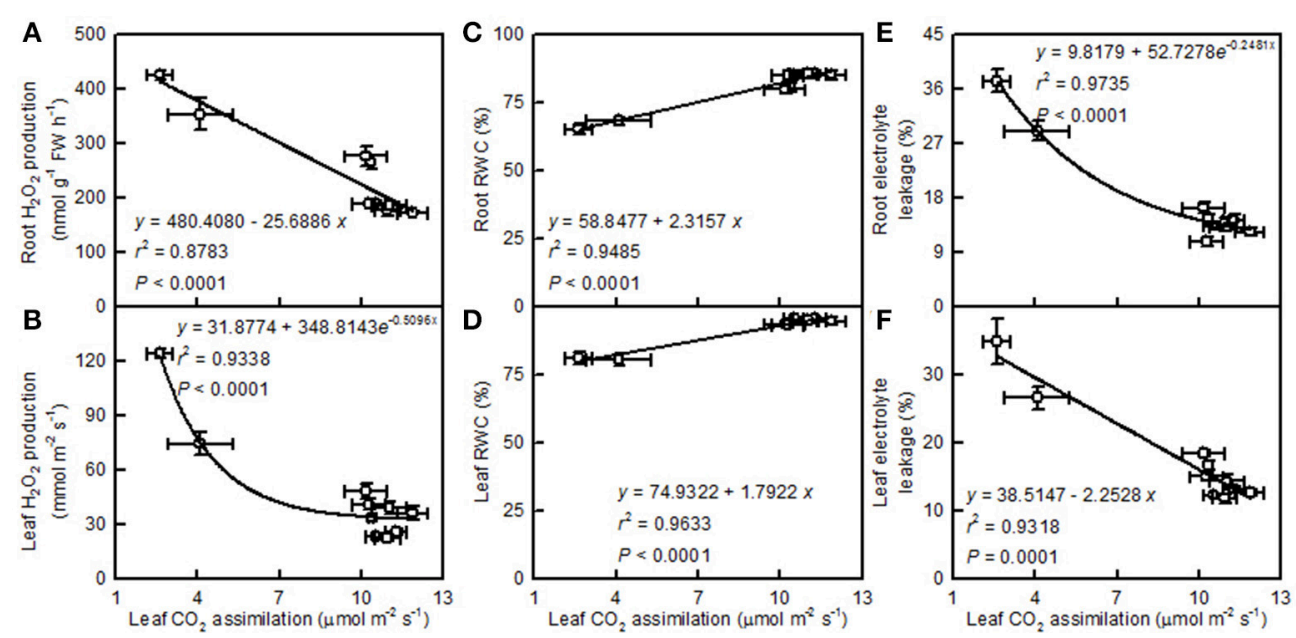

FIGURE 10 | Leaf $\mathrm{CO}_{2}$ assimilation in relation to root (A,C,E) and leaf (B,D,F) $\mathrm{H}_{2} \mathrm{O}_{2}$ production $(A, B), R W C(C, D)$, and electrolyte leakage (E,F). Points represent means $\pm \mathrm{SE}$ for the independent variable $(n=4)$ and the dependent variables $(n=4)$. Data for $\mathrm{CO}_{2}$ assimilation came from Figure 3. Data for $\mathrm{H}_{2} \mathrm{O}_{2}$ production, RWC, and electrolyte leakage came from Figure 9. Data for the two citrus species were pooled together.

citrus rootstocks (Fang, 2011; Fang et al., 2011), as well as for C. sinensis seedlings (Guest and Chapman, 1944). Based on the present results, we conclude that the two citrus species studied were insensitive to low $\mathrm{pH}$. This above conclusion is supported by the fact that most of physiological parameters monitored in Figures 3, 4, 7, 9 were altered only at $\mathrm{pH} 2.5$, and that $\mathrm{pH} 4$ had almost no influence on these parameters and the OJIP transients (Figure 6).

As shown in Figure 2B, mottled bleached leaves were observed only in the $\mathrm{pH}$ 2.5-treated $C$. grandis seedlings (Figure 2B). Furthermore, the $\mathrm{pH} 2.5$-induced alterations of many physiological parameters shown in Figures 3, 4, 7, 9, and of the JIP transients (Figure 6), were slightly greater in C. grandis than in $C$. sinensis leaves. Evidently, when the results are taken together, seedlings of $C$. sinensis had a slightly higher tolerance to a low $\mathrm{pH}$ than did those of $C$. grandis. However, the difference in low $\mathrm{pH}$ tolerance between the C. grandis and C. sinensis species is apparently lower than the difference between them in their Altolerance (Yang L. T. et al., 2011; Jiang et al., 2015; Li et al., 2016). This latter discrepancy is supported by a study showing that plant races were separately adapted to $\mathrm{Al}^{3+}$ or low $\mathrm{pH}-\left(\mathrm{H}^{+}-\right)$toxicity (Kidd and Proctor, 2001).

We found that $\mathrm{pH} 2.5$ greatly inhibited the $\mathrm{CO}_{2}$ assimilation in C. grandis and C. sinensis leaves, and that this inhibition was slightly greater in $C$. grandis than in $C$. sinensis leaves (Figure 3A). The $\mathrm{pH}$ 2.5-induced decrease in leaf $\mathrm{CO}_{2}$ assimilation could not be explained only by decreased stomatal conductance, because the intercellular $\mathrm{CO}_{2}$ concentration increased and stayed unchanged in $\mathrm{pH}$ 2.5-treated C. granddis and $C$. sinensis leaves, respectively (Figure 3C), and because leaf $\mathrm{CO}_{2}$ assimilation decreased with the increasing intercellular $\mathrm{CO}_{2}$ concentration (Figure 5B). Thus, the $\mathrm{pH}$ 2.5-induced decrease in leaf $\mathrm{CO}_{2}$ assimilation in citrus may be primarily driven by non-stomatal factors.
In this context, the $\mathrm{pH}$ 2.5-induced decreases in $\mathrm{Chl}$ a, Chl $\mathrm{b}$, and $\mathrm{Chl} \mathrm{a}+\mathrm{b}$ were probably not the main factor inhibiting leaf $\mathrm{CO}_{2}$ assimilation because their reductions were much lower than that for leaf $\mathrm{CO}_{2}$ assimilation (Figures 3A, 4A-C). This conclusion is supported by our results showing that $\mathrm{DI}_{\mathrm{o}} / \mathrm{RC}$, $\mathrm{DI}_{\mathrm{o}} / \mathrm{ABS}, \mathrm{NPQ}$, and $\mathrm{qNP}$ were all elevated in the $\mathrm{pH}$ 2.5-treated C. grandis and C. sinensis leaves (Figures 7F,G,N,O).

The observed positive $\Delta \mathrm{L}$-band at ca. $130 \mu \mathrm{s}$ in the OJIP transients from the $\mathrm{pH}$ 2.5-treated leaves (Figures 6E,J) suggested that the grouping (stability) of the PSII units and the energy exchange between the independent PSII units were both reduced (Strasser et al., 2004; Liao et al., 2015). This interpretation is further supported by our result that $\mathrm{P}_{2 \mathrm{G}}$ was decreased in the $\mathrm{pH}$ 2.5-treated leaves (Figure $7 \mathbf{K}$ ). The appearance of a positive $\Delta \mathrm{K}$-band at $300 \mu \mathrm{s}$ in the OJIP transients from the $\mathrm{pH}$ 2.5-treated leaves (Figures $6 \mathrm{C}, \mathrm{H}$ ) indicated that the oxygen evolving complex (OEC) had been damaged (Srivastava et al., 1997). The observed positive $\Delta \mathrm{J}$ - and $\Delta \mathrm{I}$-bands at $2 \mathrm{~ms}$ and $30 \mathrm{~ms}$, respectively, in the OJIP transients from the $\mathrm{pH}$ 2.5-treated leaves (Figures $6 \mathrm{C}, \mathbf{H}$ ) suggested that the reduction of the PSII acceptor side had been elevated (Strasser et al., 2004). The amount of electrons from the RCs at the acceptor side depends on both the capacity of electron donation to the RCs and the capacity of the electron transport chain from the RCs to the electron acceptors. Based on these results, we conclude that at $\mathrm{pH} 2.5$, the PSII acceptor side was more severely damaged than was the PSII donor side. We observed that $\mathrm{pH} 2.5$ led to increased $\mathrm{DI}_{\mathrm{o}} / \mathrm{RC}$, decreased $\mathrm{F}_{\mathrm{v}} / \mathrm{F}_{\mathrm{m}}$ and $\mathrm{ET}_{\mathrm{o}} / \mathrm{ABS}$ (Figures $7 \mathbf{F}, \mathbf{H}, \mathbf{I}$ ), and altered the OJIP transients (Figure 6) in leaves, together indicating that photoinhibition damaged the PSII complexes in these citrus leaves (Maxwell and Johnson, 2000; Force et al., 2003). In the present study, the $\mathrm{pH}$ 2.5-induced decrease in $\mathrm{F}_{\mathrm{v}} / \mathrm{F}_{\mathrm{m}}$ was caused by an increased $F_{0}$, since the $F_{m}$ slightly increased with 

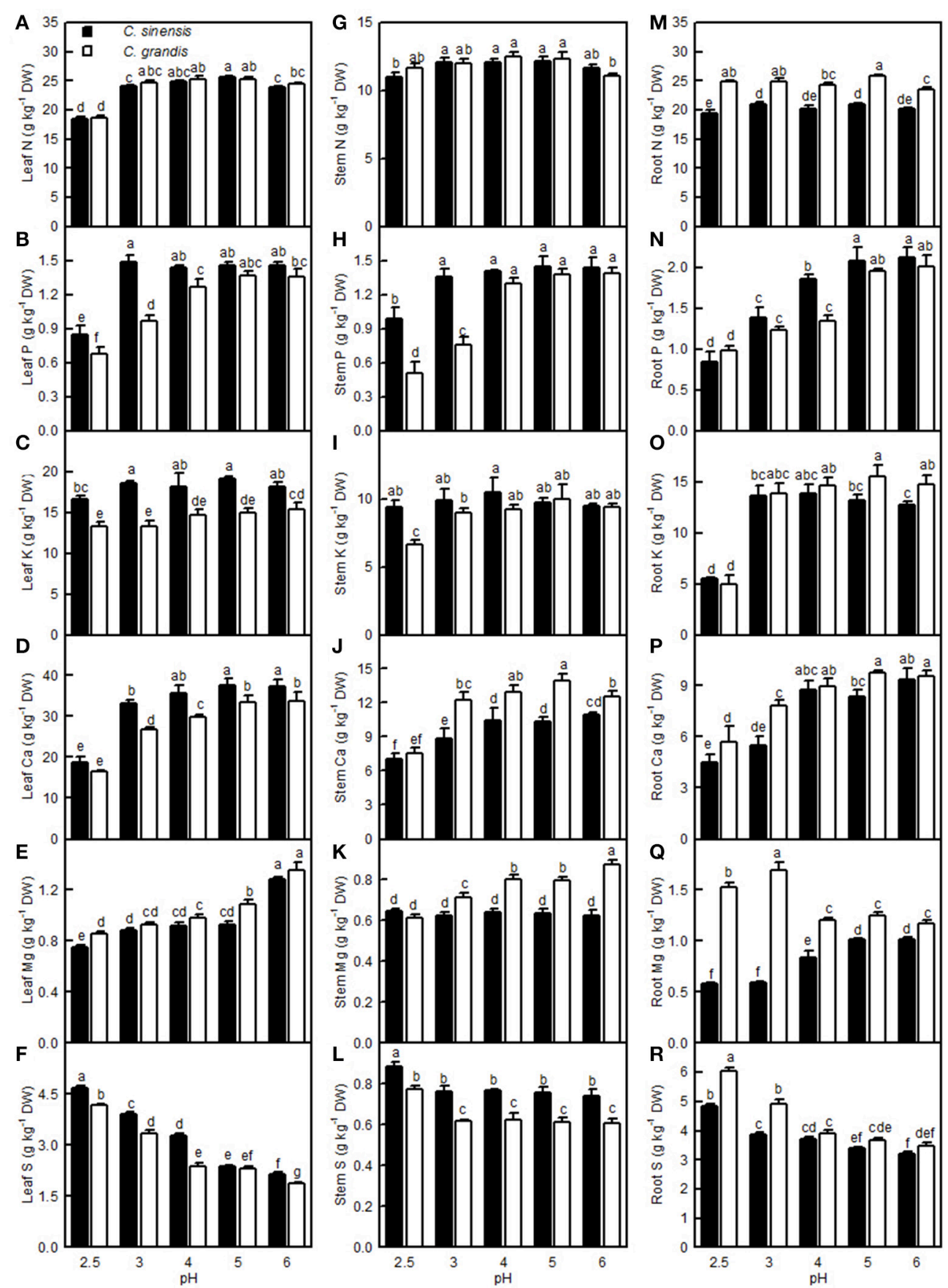

FIGURE 11 | Effects of pH on the $N(A, G, M), P(B, H, N), K(C, I, O), C a(D, J, P), M g(E, K, Q)$, and S (F,L,R) concentrations in C. sinensis and C. grandis leaves, stems, and roots. Bars represent means \pm SE $(n=4)$. Differences among the 10 treatments were analyzed by two $($ species $) \times$ five $(p H)$ factorial ANOVA. Different letters above the bars indicate a significant difference at $P<0.05$.

decreasing $\mathrm{pH}$ (Figures 7A,B). The observed higher $\mathrm{F}_{\mathrm{o}}$ in the $\mathrm{pH}$ 2.5-treated leaves was likely associated with an increased inactivation of the PSII RCs, as increased by the decreased $\mathrm{qP}$ (Figure 7M), and with the enhanced damage to OEC, as indicated by the positive $\Delta \mathrm{K}$-band (Figures $6 \mathrm{C}, \mathbf{H}$ ). Furthermore, the higher $\mathrm{F}_{\mathrm{O}}$ may have arisen from the $\mathrm{pH}$ 2.5-induced accumulation of reduced $Q_{A}$ (Bukhov et al., 1990), as indicated by the increased $\mathrm{M}_{\mathrm{O}}$ (Figure 7D). In addition, the $\mathrm{pH}$ 2.5treated leaves displayed decreased $\mathrm{RE}_{\mathrm{o}} / \mathrm{ABS}, \mathrm{PI}_{\text {tot,abs }}, \mathrm{F}_{\mathrm{m}}{ }^{\prime} / \mathrm{F}_{\mathrm{v}}{ }^{\prime}$, $\Phi_{\text {PSII }}$, and ETR (Figures 7J,L,P-R). Obviously, treatment with $\mathrm{pH} 2.5$ impaired the whole electron transport chain from the donor side of PSII to the reduction of the PSII end 

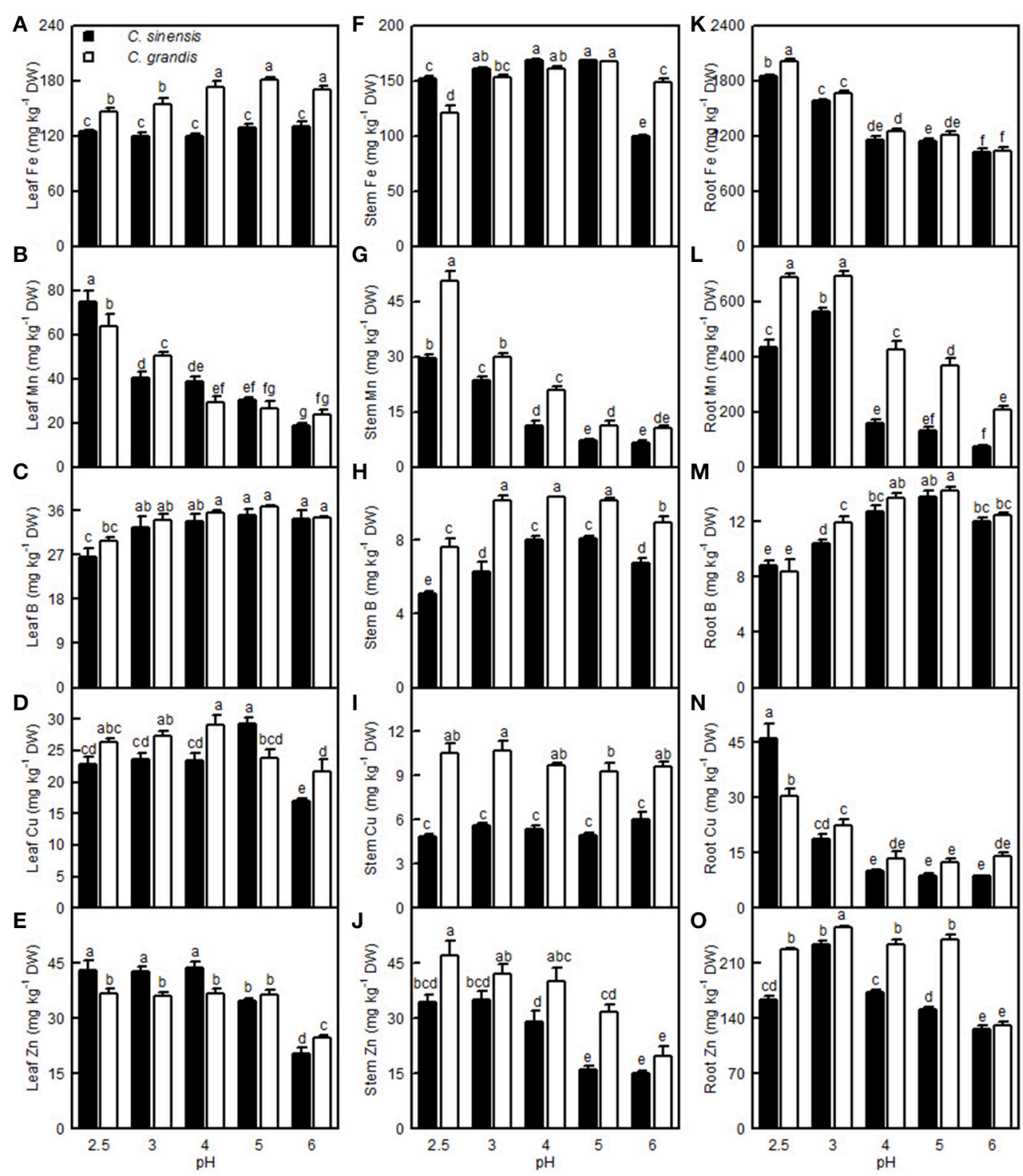

FIGURE 12 | Effects of pH on the Fe (A,F,K), Mn (B,G,L), B (C,H,M), Cu (D,I,N), and Zn (E,J,O) concentrations in the C. sinensis and C. grandis leaves, stems, and roots. Bars represent means $\pm \mathbf{S E}(\boldsymbol{n}=\mathbf{4})$. Differences among the 10 treatments were analyzed by two $($ species $) \times$ five $(p H)$ factorial ANOVA. Different letters above the bars indicate a significant difference at $P<0.05$.

acceptors, thus decreasing ETR. Regression analysis showed that leaf $\mathrm{CO}_{2}$ assimilation increased with increasing $\mathrm{F}_{\mathrm{v}} / \mathrm{F}_{\mathrm{m}}$, $\mathrm{ET}_{\mathrm{o}} / \mathrm{ABS}, \mathrm{RE}_{\mathrm{o}} / \mathrm{ABS}, \mathrm{P}_{2 \mathrm{G}}, \mathrm{PI}_{\text {tot,abs }}, \mathrm{qP}, \mathrm{F}_{\mathrm{m}}{ }^{\prime} / \mathrm{F}_{\mathrm{v}}{ }^{\prime}, \Phi_{\mathrm{PSII}}$, or ETR, (Figures 8H-M,P-R). Based on these results, we conclude that $\mathrm{pH} 2.5$ damaged the whole photosynthetic electron transport chain, thus inhibiting leaf $\mathrm{CO}_{2}$ assimilation in seedlings of these two citrus species.

Light-driven ROS production can cause oxidative damage to vital photosynthetic components and thereby inhibit photosynthesis (Foyer and Shigeoka, 2011). We observed that $\mathrm{pH} 2.5$ greatly increased the $\mathrm{H}_{2} \mathrm{O}_{2}$ production and the electrolyte leakage in C. grandis and C. sinensis leaves, though more so in the C. grandis leaves (Figures $\mathbf{9 G}, \mathbf{H}$ ), and that leaf $\mathrm{CO}_{2}$ assimilation decreased with increasing leaf $\mathrm{H}_{2} \mathrm{O}_{2}$ production and electrolyte leakage (Figures 10B,F). Hence, the observed higher ROS production may be responsible for the $\mathrm{pH}$ 2.5-induced inhibition of photosynthesis in citrus leaves.

The leaf photosynthetic rate decreases with decreasing leaf RWC (Lawlor, 2002). However, the relative importance of stomatal and non-stomatal limitations to photosynthesis under water stress is not yet fully understood. Typically, as the RWC decreases, the stomatal limitation of photosynthesis will also decrease and the metabolic limitation will increase (Lawlor, 2002; Zhou et al., 2007), which entails limitations to ribulose-1,5disphosphate $(\mathrm{RuBP})$ regeneration (Gunasekera and Berkowitz, 


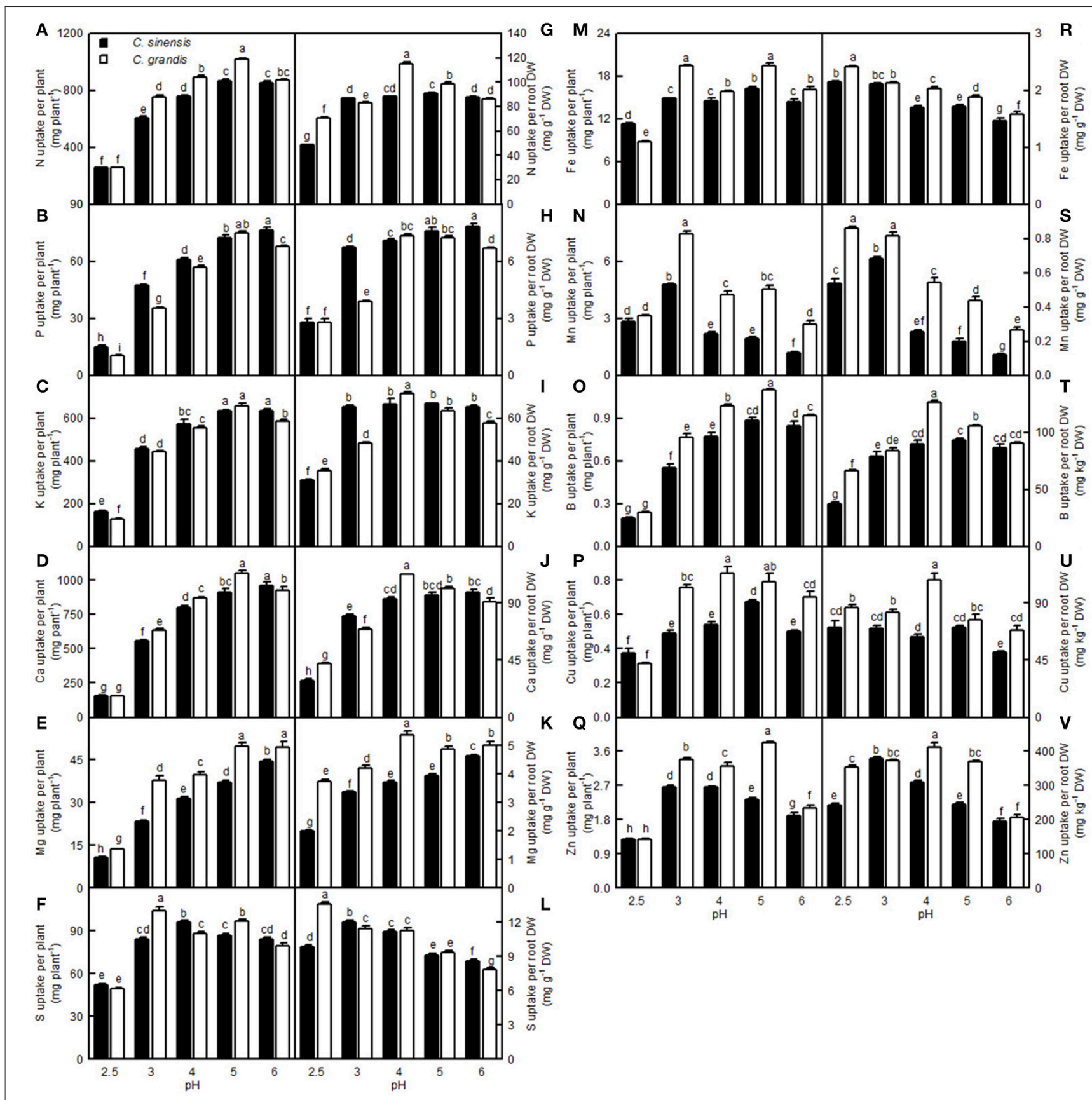

FIGURE 13 | Effects of pH on mineral element uptake per plant (A-F,M-Q) and per root DW $(\mathbf{G}-\mathbf{L}, \mathbf{R}-\mathbf{V})$. Bars represent means \pm SE $(n=4)$. Differences among the 10 treatments were analyzed by two (species) $\times$ five $(\mathrm{pH})$ factorial ANOVA. Different letters above the bars indicate a significant difference at $P<0.05$.

1993), photophosphorylation (Tezara et al., 1999), and Rubisco activity (Maroco et al., 2002; Parry et al., 2002). Zhou et al. (2007) observed that water stress decreased photosynthetic rate, Rubisco activity, the energy flux via linear electron transport, and increased $\Delta \mathrm{pH}^{-}$and xanthophyll-mediated thermal dissipation. Our results showed that the $\mathrm{pH} 2.5$-induced decrease in leaf $\mathrm{CO}_{2}$ assimilation (Figure 3A) was accompanied by decreases in root and leaf RWC (Figures 9A,F), leaf Rubisco activity (Figure 3F) and ETR, and by an increase in NPQ (Figures 7O,R). Furthermore, leaf $\mathrm{CO}_{2}$ assimilation decreased with decreasing root RWC, leaf RWC (Figures 10C,D), Rubisco activity (Figure 5C), or ETR (Figure 8R), and with increasing NPQ (Figure 8O); leaf Rubisco activity $(y)$ increased with increasing leaf RWC $\left(y=-61.1653+0.8351 x, r^{2}=0.9174\right.$, $P<0.0001)$. Thus, it is reasonable to assume that a low $\mathrm{pH}$ lowered the water uptake and induced water stress, thus 


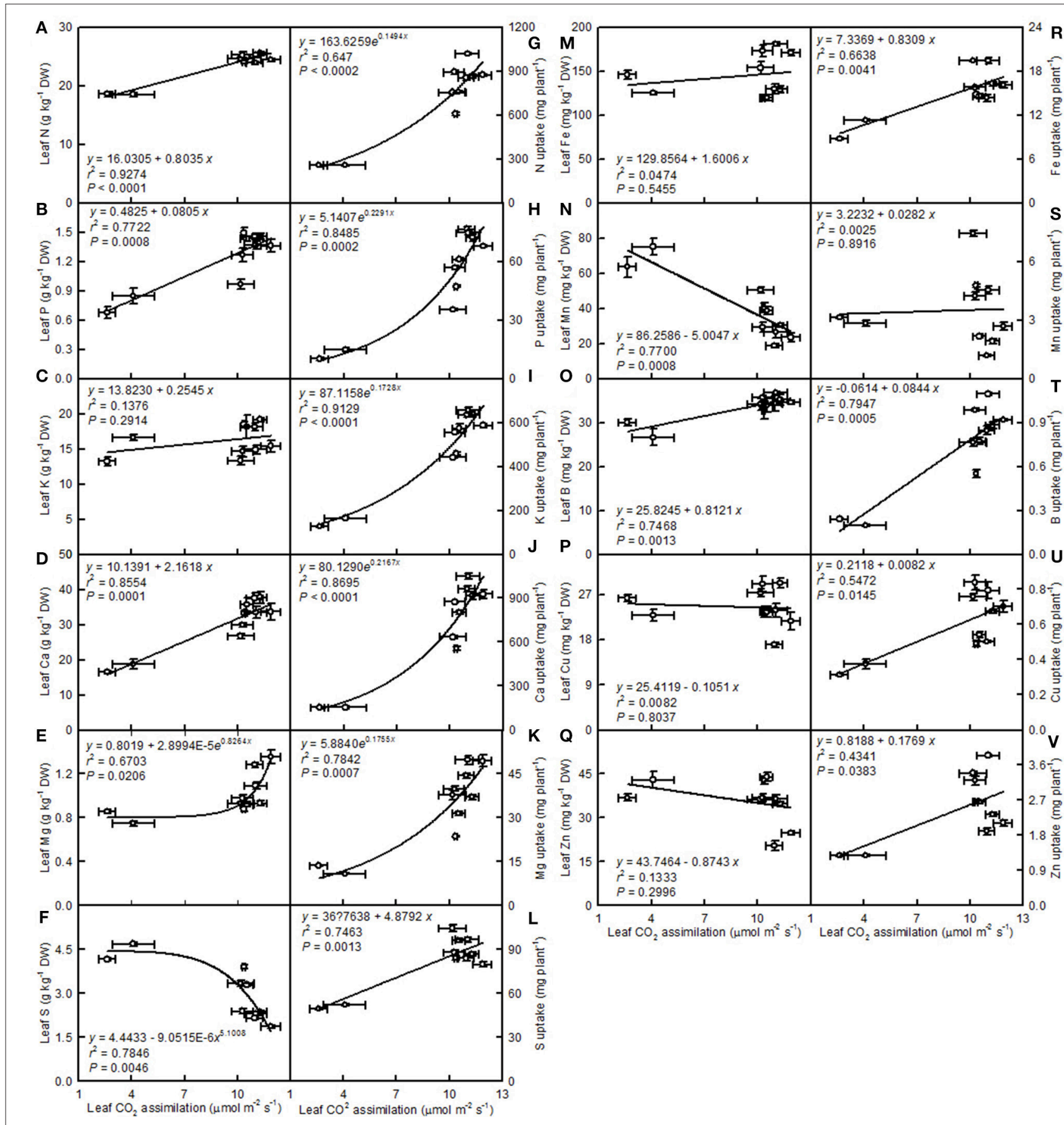

FIGURE 14 | Leaf $\mathrm{CO}_{2}$ assimilation in relation to the mineral element concentrations in leaves (A-F,M-Q) and their uptake per plant (G-L,R-V). Points represent means \pm SE for the independent variable $(n=4)$ and the dependent variables $(n=4)$. Data for $\mathrm{CO}_{2}$ assimilation came from Figure $\mathbf{3}$. Data for the mineral element concentrations (mineral element uptake per plant) came from Figures 11-13). Data for the two citrus species were pooled together.

inhibiting photosynthesis in the $C$. grandis and $C$. sinensis leaves.

A study has shown that the base cation-induced increase in sugar maple photosynthesis on acid soils was associated with an improved foliar nutrient status (St Clair and Lynch, 2005).
Ellsworth and Liu (1994) suggested that leaf photosynthesis of sugar maple on acidic soils was co-limited by $\mathrm{N}$ and $\mathrm{Ca}$, or by interactions of $\mathrm{Ca}$ with other nutrients, such as $\mathrm{Mg}$. We observed that leaf $\mathrm{CO}_{2}$ assimilation decreased with increasing leaf $\mathrm{N}, \mathrm{P}, \mathrm{Ca}$, or $\mathrm{Mg}$ concentrations $(\mathrm{N}, \mathrm{P}, \mathrm{Ca}$, or $\mathrm{Mg}$ uptake per 
plant) (Figures 14A,B,D,E,G,H,J,K). Thus, the $\mathrm{pH}$ 2.5-induced decreases in these nutrients might be responsible for the observed lower leaf $\mathrm{CO}_{2}$ assimilation.

Our results also showed that the growth of seedlings (Figures 1, 2) and the status of many of their physiological parameters (Figures 3, 4, 7, 9, 11, 12) reached their maximum at $\mathrm{pH}$ 5. This seems to contradict the early view that serious problems for citrus might arise when the soil $\mathrm{pH}$ was 5.0 or lower (Chapman, 1968). In our study, citrus seedlings were grown under favorable conditions of mineral nutrients and the direct toxicity of $\mathrm{H}^{+}$might be the primary cause for the poor seedling growth. However, a significant difference might also occur when citrus are grown on acidic soils due to the increased solubility of $\mathrm{Al}$ and $\mathrm{Mn}$, and/or decreased availability of $\mathrm{P}, \mathrm{Ca}, \mathrm{Mg}$, and Mo (George et al., 2012; Kochian et al., 2015; Li et al., 2015). Thus, the optimum $\mathrm{pH}$ for citrus might be higher in a soil culture than when grown in solution or a sand culture (Yuda and Okamoto, 1965). These findings indicate that suitable fertilizers might alleviate the toxicity of acidic soils upon citrus. Adjusting the soil nutrients via careful fertilization should contribute to greater harvest yield and the sustainable management of citrus across a range of acidic soils.

\section{CONCLUSION}

Our results demonstrate that citrus seedlings were insensitive to low $\mathrm{pH}$, and that $C$. sinensis is slightly more tolerant to this low $\mathrm{pH}$ than is $C$. grandis. $\mathrm{H}^{+}$-toxicity could directly damage the citrus roots, thus affecting their uptake of mineral nutrients and water. The results suggest that the low $\mathrm{pH}$-induced inhibition of growth was caused by the combination of $\mathrm{H}^{+}$-toxicity,

\section{REFERENCES}

Anugoolprasert, O., Kinoshita, S., Naito, H., Shimizu, M., and Ehara, H. (2012). Effect of low $\mathrm{pH}$ on the growth, physiological characteristics and nutrient absorption of sago palm in a hydroponic system. Plant Prod. Sci. 15, 125-131. doi: 10.1626/pps.15.125

Arduini, I., Kettner, C., Godbold, D. L., Onnis, A., and Stefani, A. (1998). The influence of $\mathrm{pH}$ on root morphology and mineral content of Pinus pinaster Ait. seedlings. Plant Biosyst. 132, 3-9. doi: 10.1080/11263504.1998.10654185

Baker, N. R. (2008). Chlorophyll fluorescence: a problem of photosynthesis in vivo. Annu. Rev. Plant Biol. 59, 89-113. doi: 10.1146/annurev.arplant.59.032607.092759

Bian, M., Zhou, M., Sun, D., and Li, C. (2013). Molecular approaches unravel the mechanism of acid soil tolerance in plants. Crop J. 1, 91-104. doi: 10.1016/j.cj.2013.08.002

Bradford, M. M. (1976). A rapid and sensitive method for quantitation of microgram quantities of protein utilizing the principle of proteindye binding. Anal. Biochem. 72, 248-254. doi: 10.1016/0003-2697(76) 90527-3

Bukhov, N. G., Sabat, S. C., and Mohanty, P. (1990). Analysis of chlorophyll a fluorescence changes in weak light in heat treated Amaranthus chloroplasts. Photosynth. Res. 23, 81-87. doi: 10.1007/BF00030066

Chapman, H. D. (1968). “The mineral nutrition of citrus," in The Citrus Industry, Vol. 2, eds W. Reuther, H. J. Webber, and L. D. Batchelor (Berkeley, CA: Division of Agricultural Sciences, University of California), 127-189.

Chen, L. S., and Cheng, L. (2009). Photosystem 2 is more tolerant to high temperature in apple (Malus domestica Borkh.) leaves than deficiencies of nutrients, and decreased water uptake. Here, only pH 2.5 noticeably inhibited leaf $\mathrm{CO}_{2}$ assimilation, which was probably due to the combination of an impaired photosynthetic electron transport chain, increased ROS production, and decreased uptake of water and nutrients. In sum, these findings increase our understanding of the factors by which a low $\mathrm{pH}$ can decrease citrus growth, and of the mechanisms by which low $\mathrm{pH}$ inhibits leaf $\mathrm{CO}_{2}$ assimilation.

\section{AUTHOR CONTRIBUTIONS}

AL performed most of the experiment and drafted the manuscript; JZ participated in the measurements of photosynthesis and fluorescence; LY participated in the direction of this study; XY and NL participated in the analysis of the nutrient elements; LT and DL participated in the cultivation of the experimental seedlings; LC designed and directed the study and also revised the manuscript. All authors have read and approved the final manuscript.

\section{FUNDING}

This work was financially supported by an earmarked fund for the China Agriculture Research System (No. CARS27).

\section{SUPPLEMENTARY MATERIAL}

The Supplementary Material for this article can be found online at: http://journal.frontiersin.org/article/10.3389/fpls.2017. 00185/full\#supplementary-material in fruit peel. Photosynthetica 47, 112-120. doi: 10.1007/s11099-0090017-4

Chen, L. S., Qi, Y. P., and Liu, X. H. (2005b). Effects of aluminum on light energy utilization and photoprotective systems in citrus leaves. Ann. Bot. 96, 35-41. doi: 10.1093/aob/mci145

Chen, L. S., Qi, Y. P., Smith, B. R., and Liu, X. H. (2005a). Aluminum-induced decrease in $\mathrm{CO} 2$ assimilation in citrus seedlings is unaccompanied by decreased activities of key enzymes involved in $\mathrm{CO}_{2}$ assimilation. Tree Physiol. 25, 317-324. doi: 10.1093/treephys/25.3.317

Ellsworth, D. S., and Liu, X. (1994). Photosynthesis and canopy nutrition of four sugar maple forests on acid soils in northern Vermont. Can. J. For. Res. 24, 2118-2127. doi: 10.1139/x94-272

Fang, Z. J. (2011). Evaluation of Acid Tolerance for Citrus Rootstock Seedlings and Their Differences in Physiological Characteristics. Master thesis, Jiangxi Agricultural University, Nanchang.

Fang, Z. J., Yang, L. L., Huang, C. H., Gu, Q. Q., and Xu, X. B. (2011). Analysis on acid tolerance of several citrus rootstock seedlings. South China Fruits 40, 8-11.

Force, L., Critchley, C., and van Rensen, J. J. S. (2003). New fluorescence parameters for monitoring photosynthesis in plants. 1. The effect of illumination on the fluorescence parameters of the JIP-test. Photosynth. Res. 78, 17-33. doi: 10.1023/A:1026012116709

Foyer, C. H., and Shigeoka, S. (2011). Understanding oxidative stress and antioxidant functions to enhance photosynthesis. Plant Physiol. 155, 93-100. doi: $10.1104 /$ pp.110.166181

Genty, B., Harbinson, J., and Baker, N. R. (1990). Relative quantum efficiencies of the two photosystems of photorespiratory and non-respiratory conditions. Plant Physiol. Biochem. 28, 1-10. 
George, E., Horst, W. J., and Neumann, E. (2012). "Adaptation of plants to adverse chemical soil conditions," in Marschner's Mineral Nutrition of Higher Plants, 3rd Edn., ed P. Marschner (London: Academic Press), 409-472.

Guest, P. L., and Chapman, H. D. (1944). Some effects of $\mathrm{pH}$ on the growth of citrus in sand and solution cultures. Soil Sci. 58, 455-466. doi: 10.1097/00010694-194412000-00005

Gunasekera, D., and Berkowitz, G. A. (1993). Use of transgenic plants with Rubisco antisense DNA to evaluate the rate limitation of photosynthesis under water stress. Plant Physiol. 103, 629-635. doi: 10.1104/pp.103. 2.629

Gunsé, B., Poschenrieder, C., and Barceló, J. (1997). Water transport properties of roots and root cortical cells in proton- and Al-stressed maize varieties. Plant Physiol. 113, 595-602. doi: 10.1104/pp.113.2.595

Han, S., Chen, L. S., Jiang, H. X., Smith, B. R., Yang, L. T., and Xie, C. Y. (2008). Boron deficiency decreases growth and photosynthesis, and increases starch and hexoses in leaves of citrus seedlings. J. Plant Physiol. 165, 1331-1341. doi: 10.1016/j.jplph.2007.11.002

He, Z. L., Alva, A. K., Calvert, D. V., Li, Y. C., and Banks, D. J. (1999). Effects of nitrogen fertilization of grapefruit trees on soil acidification and nutrient availability in a Riviera fine sand. Plant Soil 206, 11-19. doi: 10.1023/A:1004364805789

Islam, A. K. M. S., Edwards, D. G., and Asher, C. J. (1980). pH optima for crop growth. Results of a flowing solution culture experiment with six species. Plant Soil 54, 339-357. doi: 10.1007/BF02181830

Jiang, H. X., Chen, L. S., Zheng, J. G., Han, S., Tang, N., and Smith, B.R. (2008). Aluminum-induced effects on photosystem II photochemistry in citrus leaves assessed by the chlorophyll a fluorescence transient. Tree Physiol. 28, 1863-1871. doi: 10.1093/treephys/28.12.1863

Jiang, H. X., Yang, L. T., Qi, Y. P., Lu, Y. B., Huang, Z. R., and Chen, L. S. (2015). Root iTRAQ protein profile analysis of two citrus species differing in aluminum-tolerance in response to long-term aluminum-toxicity. $B M C$ Genomics 16:949. doi: 10.1186/s12864-015-2133-9

Kamaluddin, M., and Zwiazek, J. J. (2004). Effects of root medium pH on water transport in paper birch (Betula papyrifera) seedlings in relation to root temperature and abscisic acid treatments. Tree Physiol. 24, 1173-1180. doi: 10.1093/treephys/24.10.1173

Kidd, P. S., and Proctor, J. (2001). Why plants grow poorly on very acid soils: are ecologists missing the obvious? J. Exp. Bot. 52, 791-799. doi: 10.1093/jexbot/52.357.791

Kochian, L. V., Piñeros, M. A., Liu, J., and Magalhaes, J. V. (2015). Plant adaptation to acid soils: the molecular basis for crop aluminum resistance. Annu. Rev. Plant Biol. 66, 571-598. doi: 10.1146/annurev-arplant-043014-114822

Kowalenko, C. G., and Lavkulich, L. M. (1976). A modified curcumin method for boron analysis of soil extracts. Can. J. Soil Sci. 56, 537-539. doi: $10.4141 /$ cjss $76-068$

Koyama, H., Toda, T., and Hara, T. (2001). Brief exposure to low-pH stress causes irreversible damage to the growing root in Arabidopsis thaliana: pectin-Ca interaction may play an important role in proton rhizotoxicity. J. Exp. Bot. 52, 361-368. doi: 10.1093/jexbot/52.355.361

Lawlor, D. W. (2002). Limitation to photosynthesis in water-stressed leaves: stomata vs. metabolism and the role of ATP. Ann. Bot. 89, 871-885. doi: $10.1093 / \mathrm{aob} / \mathrm{mcf1} 10$

Li, H., Yang, L. T., Qi, Y. P., Gu, P., Lu, Y. B., and Chen, L. S. (2016). Aluminumtoxicity-induced alterations of leaf proteome in two citrus species differing in aluminum-tolerance. Int. J. Mol. Sci. 17:1180. doi: 10.3390/ijms17071180

Li, Y., Han, M. Q., Lin, F., Ten, Y., Lin, J., Zhu, D. H., et al. (2015). Soil chemical properties, 'Guanximiyou' pummelo leaf mineral nutrient status and fruit quality in the southern region of Fujian province, China. J. Soil Sci. Plant Nutr. 15, 615-628. doi: 10.4067/s0718-95162015005000029

Liao, X. Y., Yang, L. T., Lu, Y. B., Ye, X., and Chen, L. S. (2015). Roles of rootstocks and scions in aluminum-tolerance of citrus. Acta Physiol. Plant. 37:1743. doi: 10.1007/s11738-014-1743-1

Lichtenthaler, H. K. (1987). Chlorophylls and carotenoids: pigments of photosynthetic biomembranes. Methods Enzymol. 148, 350-382. doi: 10.1016/0076-6879(87)48036-1

Lin, Z. H., Chen, L. S., Chen, R. B., Zhang, F. Z., Jiang, H. X., and Tang, N. (2009). $\mathrm{CO}_{2}$ assimilation, ribulose-1,5-bisphosphate carboxylase/oxygenase, carbohydrates and photosynthetic electron transport probed by the JIP-test, of tea leaves in response to phosphorus supply. BMC Plant Biol. 9:43. doi: 10.1186/1471-2229-9-43

Lin, Z., and Myhre, D. L. (1990). Citrus root growth as affected by soil aluminum level under field conditions. Soil Sci. Soc. Am. J. 54, 1340-1344. doi: $10.2136 /$ sssaj1990.03615995005400050023x

Lu, R. K. (1999). Methods of Soil and Agrochemistry Analysis. Beijing: China Agriculture Science and Technology Press.

Malkanthi, D. R. R., Yokoyama, K., Yoshida, T., Moritsugu, M., and Matsushita, K. (1995). Effects of low $\mathrm{pH}$ and $\mathrm{Al}$ on growth and nutrient uptake of several plants. Soil Sci. Plant Nutr. 41, 161-165. doi: 10.1080/00380768.1995.10419571

Maroco, J. P., Rodrigues, M. L., Lopes, C., and Chaves, M. M. (2002). Limitations to leaf photosynthesis in field-grown grapevine under drought-metabolic and modelling approaches. Funct. Plant Biol. 29, 451-459. doi: 10.1071/PP01040

Martins, N., Gonçalves, S., Palma, T., and Romano, A. (2011). The influence of low $\mathrm{pH}$ on in vitro growth and biochemical parameters of Plantago almogravensis and P. algarbiensis. Plant Cell Tiss. Organ Cult. 107, 113-121. doi: 10.1007/s11240-011-9963-1

Martins, N., Gonçalves, S., and Romano, A. (2013b). Metabolism and aluminum accumulation in Plantago almogravensis and $P$. algarbiensis in response to low $\mathrm{pH}$ and aluminum stress. Biol. Plant. 57, 325-331. doi: 10.1007/s10535-012-0271-3

Martins, N., Osório, M. L., Gonçalves, S., Osório, J., Palma, T., and Romano, A. (2013a). Physiological responses of Plantago algarbiensis and P. almogravensis shoots and plantlets to low $\mathrm{pH}$ and aluminum stress. Acta Physiol. Plant. 35, 615-625. doi: 10.1007/s11738-012-1102-z

Martins, N., Osório, M. L., Gonçalves, S., Osório, J., and Romano, A. (2013c). Differences in $\mathrm{Al}$ tolerance between Plantago algarbiensis and $P$. almogravensis reflect their ability to respond to oxidative stress. Biometals 26, 427-437. doi: 10.1007/s10534-013-9625-3

Maxwell, K., and Johnson, G. N. (2000). Chlorophyll fluorescence -a practical guide. J. Exp. Bot. 51, 659-668. doi: 10.1093/jexbot/51.345.659

Panković, D., Sakač, Z., Kevrešan, S., and Plesničar, M. (1999). Acclimation to long-term water deficit in the leaves of two sunflowe hybrids: photosynthesis, electron transport and carbon metabolism. J. Exp. Bot. 50, 127-138. doi: $10.1093 /$ jexbot $/ 50.330 .127$

Parry, M. A., Andralojc, P. J., Khan, S., Lea, P. J., and Keys, A. J. (2002). Rubisco activity: effects of drought stress. Ann. Bot. 89, 833-839. doi: $10.1093 / \mathrm{aob} / \mathrm{mcf} 103$

Peng, H. Y., Qi, Y. P., Lee, J., Yang, L. T., Guo, P., Jiang, H. X., et al. (2015). Proteomic analysis of Citrus sinensis roots and leaves in response to long-term magnesium-deficiency. BMC Genomics 16:253. doi: 10.1186/s12864-015-1462-z

Randhawa, S. S., and Iwata, M. (1968). Effects of pH, calcium concentrations and sources of nitrogen on the growth and inorganic compositions of citrus seedlings in solution culture. J. Jap. Soc. Hortic. Sci. 37, 23-31. doi: 10.2503/jijshs.37.319

Schubert, S., Schubert, E., and Mengel, K. (1990). Effect of low pH of the root medium on proton release, growth, and nutrient uptake of field beans (Vicia faba). Plant Soil 124, 239-244. doi: 10.1007/BF00009266

Shi, Q. H., Zhu, Z. J., Juan, L. I., and Qian, Q. Q. (2006). Combined effects of excess $\mathrm{Mn}$ and low $\mathrm{pH}$ on oxidative stress and antioxidant enzymes in cucumber roots. Agri. Sci. China 5, 767-772. doi: 10.1016/S1671-2927(06)60122-3

Srivastava, A., Guisse, B., Greppin, H., and Strasser, R. J. (1997). Regulation of antenna structure and electron transport in photosystem II of Pisum sativum under elevated temperature probed by the fast polyphasic chlorophyll a fluorescence transient: OKJIP. Biochim. Biophys. Acta 1320, 95-106. doi: 10.1016/S0005-2728(97)00017-0

St Clair, S. B., and Lynch, J. P. (2005). Base cation stimulation of mycorrhization and photosynthesis of sugar maple on acid soils are coupled by foliar nutrient dynamics. New Phytol. 165, 581-590. doi: 10.1111/j.1469-8137.2004. 01249.x

Strasser, R. J., Tsimilli-Micheal, M., and Srivastava, A. (2004). "Analysis of the chlorophyll a fluorescence transient," in Chlorophyll a Fluorescence: A Signature of Photosynthesis, eds G. C. Papageorgiou and Govindjee (Berlin: Springer), 321-362.

Tezara, W., Mitchell, W. J., Driscoll, S. D., and Lawlor, D. W. (1999). Water stress inhibits plant photosynthesis by decreasing coupling factor and ATP. Nature 401, 914-917. doi: 10.1038/44842 
Tournaire-Roux, C., Sutka, M., Javot, H., Gout, E., Gerbeau, P., Luu, D. T., et al. (2003). Cytosolic $\mathrm{pH}$ regulates root water transport during anoxic stress through gating of aquaporins. Nature 425, 393-397. doi: 10.1038/nature01853

von Uexküll, H. R., and Mutert, E. (1995). Global extent, development and economic impact of acid soils. Plant Soil 171, 1-15. doi: 10.1007/BF00009558

Wu, D. M., Fu, Y. Q., Yu, Z. W., and Shen, H. (2013). Status of red soil acidification and aluminum toxicity in south China and prevention. Soils 45, 577-584.

Yang, L. T., Jiang, H. X., Tang, N., and Chen, L. S. (2011). Mechanisms of aluminum-tolerance in two species of citrus: secretion of organic acid anions and immobilization of aluminum by phosphorus in roots. Plant Sci. 180, 521-530. doi: 10.1016/j.plantsci.2010.11.011

Yang, L. T., Qi, Y. P., Jiang, H. X., and Chen, L. S. (2013). Roles of organic acid anion secretion in aluminium tolerance of higher plants. BioMed Res. Int. 2013:173682. doi: 10.1155/2013/173682

Yang, M., Huang, S. X., Fang, S. Z., and Huang, X. L. (2011). Response of seedling growth of four Eucalyptus clones to acid and aluminum stress. Plant Nutr. Fert. Sci. 17, 195-201.

Yang, M., Tan, L., Xu, Y., Zhao, Y., Cheng, F., Ye, S., et al. (2015). Effect of low pH and aluminum toxicity on the photosynthetic characteristics of different fastgrowing Eucalyptus vegetatively propagated clones. PLoS ONE 10:e130963. doi: 10.1371/journal.pone.0130963

Yuda, E., and Okamoto, S. (1965). The effect of soil reaction on the growth of young citrus plants. I. Forms of nitrogen fertilizer and kinds of $\mathrm{pH}$ adjusting agent. J. Jap. Soc. Hortic. Sci. 34, 177-186. doi: 10.2503/jjshs.34.177
Zhang, C. P., Meng, P., Li, J. Z., and Wan, X. C. (2014). Interactive effects of soil acidification and phosphorus deficiency on photosynthetic characteristics and growth in Juglans regia seedlings. Chin. J. Plant Ecol. 38, 1345-1355. doi: 10.3724/SP.J.1258.2014. 00129

Zhang, Y. K., Zhu, D. F., Zhang, Y. P., Chen, H. Z., Xiang, J., and Lin, X. Q. (2015). Low $\mathrm{pH}$-induced changes of antioxidant enzyme and ATPase activities in the roots of rice (Oryza sativa L.) seedlings. PLoS ONE 10:e0116971. doi: 10.1371/journal.pone.0116971

Zhou, Y., Lam, H. M., and Zhang, J. (2007). Inhibition of photosynthesis and energy dissipation induced by water and high light stresses in rice. J. Exp. Bot. 58, 1207-1217. doi: 10.1093/jxb/erl291

Conflict of Interest Statement: The authors declare that the research was conducted in the absence of any commercial or financial relationships that could be construed as a potential conflict of interest.

Copyright (c) 2017 Long, Zhang, Yang, Ye, Lai, Tan, Lin and Chen. This is an openaccess article distributed under the terms of the Creative Commons Attribution License (CC BY). The use, distribution or reproduction in other forums is permitted, provided the original author(s) or licensor are credited and that the original publication in this journal is cited, in accordance with accepted academic practice. No use, distribution or reproduction is permitted which does not comply with these terms. 